\title{
The Bryan Hardy Site (41SM55), Smith County, Texas
}

Mark Walters

Heritage Research Center, Stephen F. Austin State University

Patti Haskins

Follow this and additional works at: https://scholarworks.sfasu.edu/ita

Part of the American Material Culture Commons, Archaeological Anthropology Commons, Environmental Studies Commons, Other American Studies Commons, Other Arts and Humanities Commons, Other History of Art, Architecture, and Archaeology Commons, and the United States History Commons

Tell us how this article helped you.

This Article is brought to you for free and open access by the Center for Regional Heritage Research at SFA ScholarWorks. It has been accepted for inclusion in Index of Texas Archaeology: Open Access Gray Literature from the Lone Star State by an authorized editor of SFA ScholarWorks. For more information, please contact cdsscholarworks@sfasu.edu. 


\section{The Bryan Hardy Site (41SM55), Smith County, Texas}

Creative Commons License

(c) $($ i) $(9)$

This work is licensed under a Creative Commons Attribution-NonCommercial 4.0 International License 


\title{
THE BRYAN HARDY SITE (41SM55), SMITH COUNTY, TEXAS
}

\author{
Mark Walters and Patti Haskins
}

\begin{abstract}
The authors put on record archeological data obtained by Mr. Walters' late uncle Sam Whiteside from the Bryan Hardy site (4ISM55) in Smith County, Texas. Mr. Whiteside was an active avocational archeologist in East Texas during the late 1950 s and early 1960 s, and he recorded numerous prehistoric sites on Prairie Creek and Ray Creek in Smith County, and the Jamestown (41SM54) and Boxed Springs (41UR30) mound sites on the Sabine River. An abrupt illness in mid-life prevented him from publishing his findings, and we hope that the publication of his investigations at the Bryan Hardy site will allow his work to be available to the interested public.
\end{abstract}

\section{INTRODUCTION AND SITE SETTING}

The Bryan Hardy site (41SM55) is located on a foot slope about $12 \mathrm{~m}$ above the north side of Ray Creek, which flows $2 \mathrm{~km}$ east to join Harris Creek. Harris Creek, in turn, flows north to meet the Sabine River below Winona, Texas, about $14 \mathrm{~km}$ distant. Much of the area is used for woodlands and wildlife habitats, although small areas have been cleared for pasture, and other areas have been mined for iron ore gravels; cropland use is minor. The principal vegetation is hardwoods--hickory, oak, and elm--and some pine (Hatherly 1993)

Soils at the site are the Redsprings very gravelly sandy loam, 2-5 percent slope (Hatherly 1993:41). The Redsprings soil A-horizon is a dark reddish-brown very gravelly sandy loam with an average depth of $12 \mathrm{~cm}$ overlying a B-horizon of strongly acid red clay.

These are Eocene-aged soils that formed in glauconitic materials interbedded with shale and sandy materials in the Weches Formation. They occur in irregular patches on uplands or narrow convex divides, as well as low foot slopes up to 10-200 acres in size, and they make up less than 17 percent of the soils in Smith County. They are typically found adjacent to strongly sloping or steep areas with 8-25 percent slopes. This area of Smith County is the easternmost occurrence of the soil series, with the majority of the Redsprings sediments found in the northwestern and southern parts of the county, and the soil is on the southern edge of a strip that extends along Harris Creek to the Sabine River.

\section{ARCHEOLOGICAL INVESTIGATIONS}

In 1958, Sam Whiteside located on the Hardy Farm what he thought was a low domeshaped mound about $15 \mathrm{~m}$ in diameter and a maximum of $1 \mathrm{~m}$ in height. With the aid of members of the East Texas Archeological Society (located in Tyler, Texas) and his son Jim Whiteside, he excavated portions of the mound, which contained a prehistoric Caddo circular house (House 1) with an extended entranceway. In addition, he excavated two burials adjacent to the mound, as well as parts of two other circular houses and one associated burial about $50 \mathrm{~m}$ north of the mound (Figure 1).

From a fixed datum labeled N0/E0, north-south and east-west lines were laid out over the site. Elevations were recorded from this datum, and a contour map was prepared for the House 1 area (Figure 2). Five foot square units were excavated in 6-inch levels, and most 


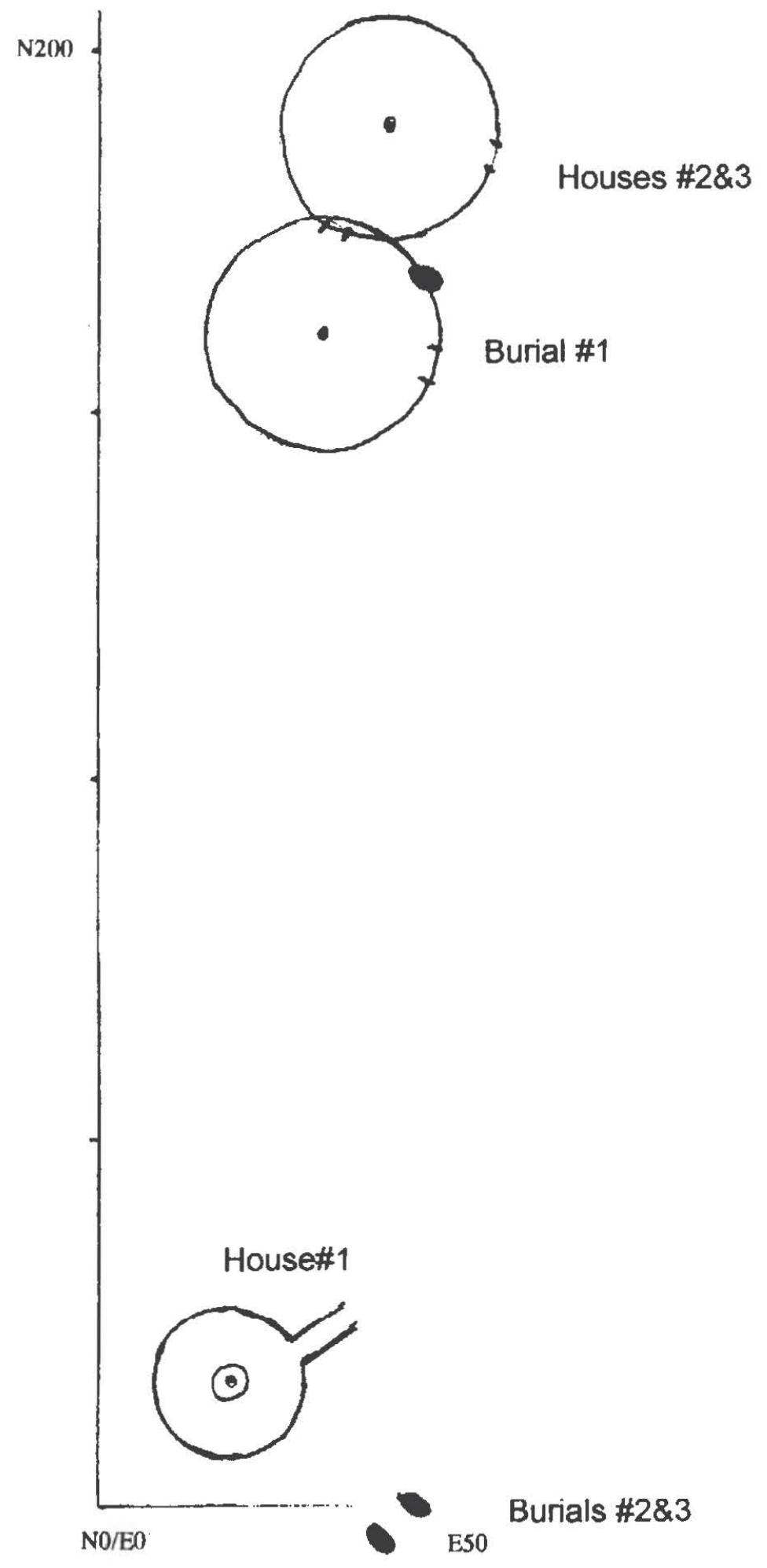

Figure 1. Three Houses and Three Burials at Bryan Hardy. 

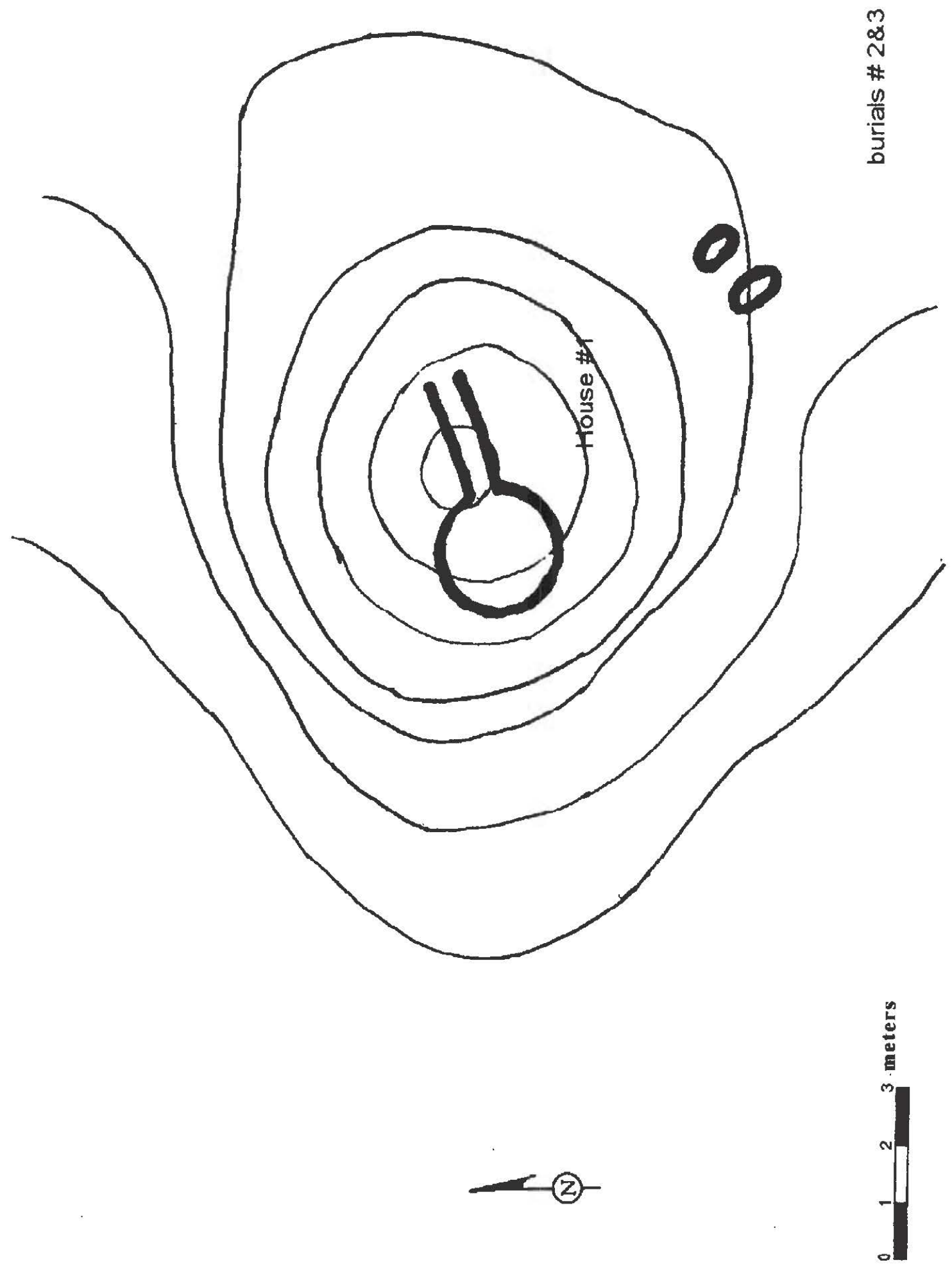

Figure 2. Contour Map of House 1 Area. 
of the soil was dry-screened through 1/4-inch hardware mesh to recover artifacts. Artifacts were assigned catalog numbers that indicated their unit and level.

\section{House 1}

House I was circular in shape, $5.48 \mathrm{~m}$ in diameter, and was built on the original ground surface. It had 61 exterior posts, $22-30 \mathrm{~cm}$ in diameter (Figure 3), with average depths of $76 \mathrm{~cm}$ below surface (bs). The house also had an extended entranceway that was $0.75 \mathrm{~m}$ wide and $3.7 \mathrm{~m}$ in length, and faced northeast (see Figure 3 ). The entrance was constructed by the Caddo digging two parallel wall trenches, and then posts from $5-13 \mathrm{~cm}$ in diameter were placed closely together in individual holes dug into the bottom of the trench, and finally packed with clay (Figure 4). When House I was burned, this clay preserved portions of some of the posts at ground level.

Mr. Whiteside collected a charcoal sample from one of the House 1 posts, and sent it to The University of Texas at Austin for analysis. However, we could find no record of any analysis, and our inquiry to Laura Nightengale at the Texas Archeological Research Laboratory (TARL) at The University of Texas led to the discovery of the sample still on the TARL. shelves.

We submitted this charred post sample to The University of Texas Radiocarbon Laboratory, and obtained a corrected radiocarbon age of $650 \pm 40$ B.P. (Tx-9276, stable carbon isotope value of $-26.8 \mathrm{o} / \mathrm{oo}$ ). Calibrating the corrected age at a 20 year interval scale for calendric dates using CALIB 3.03c, Test 10 (Stuiver and Reimer 1993a, 1993b), produced calibrated age ranges at 1-sigma of AD 1345-1391 (0.71 relative area under probability distribution) and AD $1297-1317$ (0.29 relative area under probability distribution) (Perttula I998:Table 1). There is a 67 percent chance that the calibrated age of the Bryan Hardy charred post falls between AD 1297-I391.

Mr. Whiteside speculated that House 1 had a prepared floor, as it was very compact, but he did note the same compactness in other high traffic areas. The floor level was described as very distinct, but with few artifacts other than those found around the entrance. There was evidence of a ledge of soil around part of the house, particularly by the entrance (see Figure $3)$.

A hearth with ash deposits was located in the center of House 1 (see Figure 3 ). There were also six interior posts--possibly roof support posts--and the three largest were $28 \mathrm{~cm}$ in diameter (see Figure 3).

After House 1 was burned, it was covered with approximately $1 \mathrm{~m}$ of undifferentiated soil, indicating that the mound fill was placed in one episode. There has been much research interest lately in understanding the character and purpose of these house mounds in Caddo prehistory. In particular, the evidence of burning, the subsequent covering of the house with soil, and the extended entranceways (notably the exaggerated length and encasing of the entrance) on many structures below mounds, have led to speculations about these structures being used for special purposes. To investigate the possible special purpose function of House 1, we turned to the abundant ceramic collection, hoping that some distinctions could be made about specific ceramic-related activities at the Bryan Hardy site. However, no differences were apparent between House 1 and Houses 2 and 3.

Whiteside did not fully excavate House 1, but only exposed the house outline, excavated 6 8 posts, and used a soil probe on the remainder to determine their depths. He then backfilled the excavations. In a 1958 letter to E. Mott Davis at The University of Texas, he 


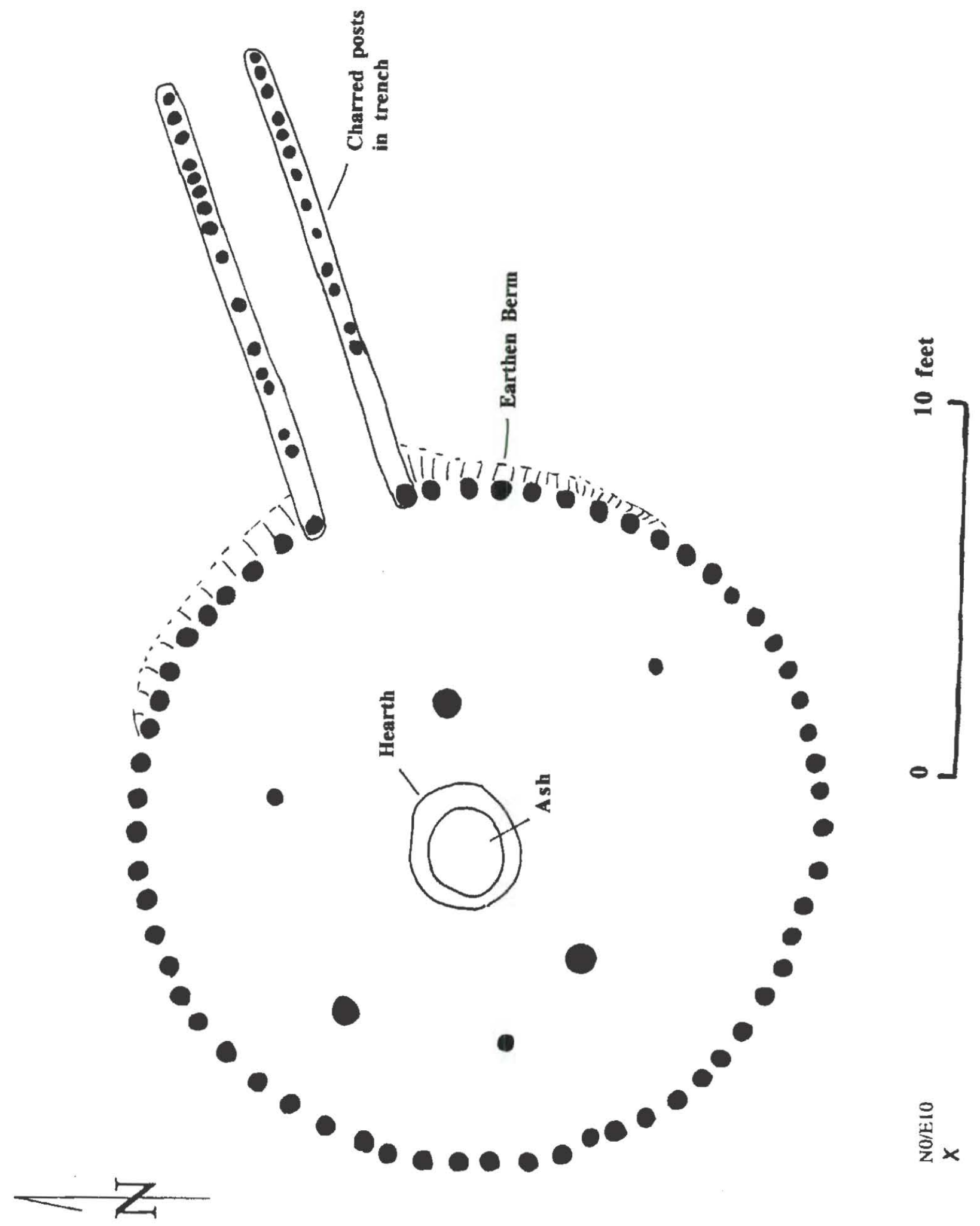

Figure 3. Plan of Features and Post Holes, House 1. 


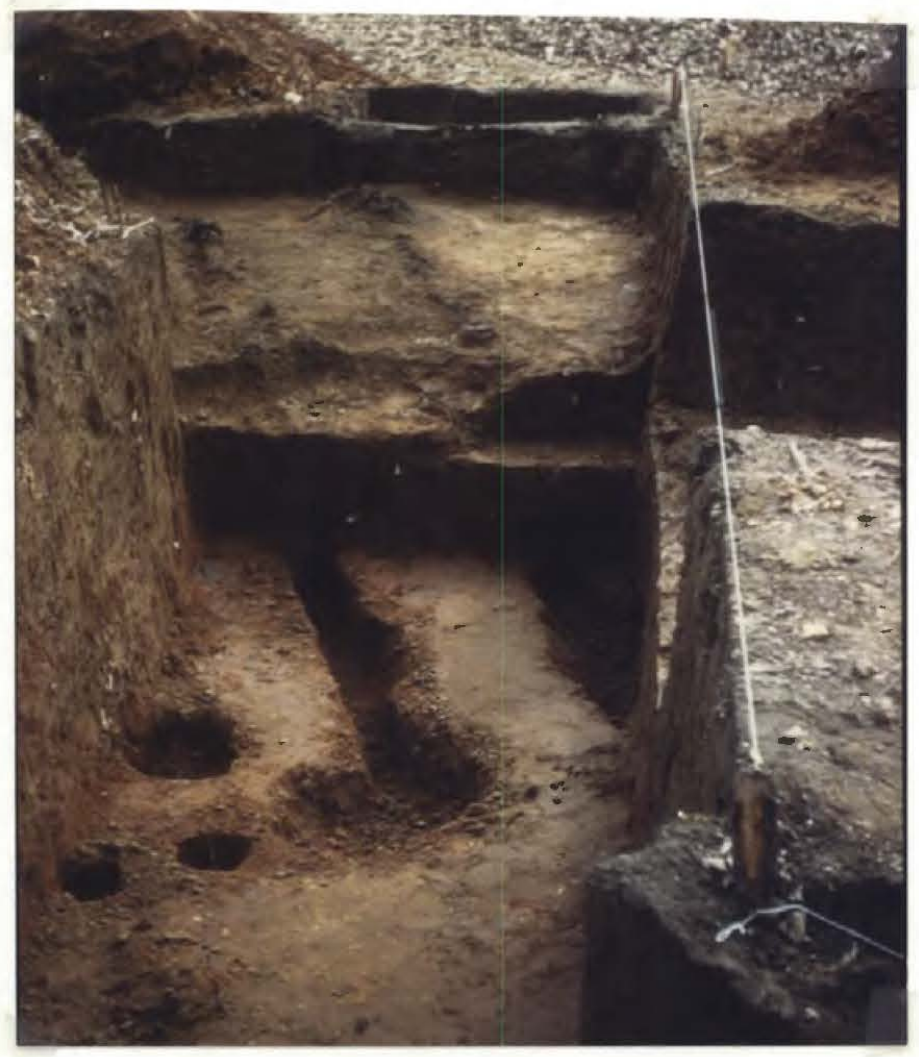

Figure 4. Extended entrance, House 1.

stated: "I pushed quite a bit of dirt back over the house plan, as I promised the landowner I would smooth the place over, this should preserve the plan for posterity."

\section{Houses 2 and 3}

These houses were about $45 \mathrm{~m}$ north of House 1 (see Figure 1), and consisted of overlapping circular house patterns (Figure 5). House 2 was $10.4 \mathrm{~m}$ in diameter, and was constructed of poles placed in the ground that were approximately $90 \mathrm{~cm}$ apart. The interior of the house was not fully excavated, but an interior central hearth was discovered during the work. Under the hearth was the centerpost; it extended to $81 \mathrm{~cm}$ bs. A $0.9 \mathrm{~m}$ gap in the sequence of exterior posts on the east side was thought to be the entrance to the house. There was no evidence of burning or daub associated with House 2. One burial (Burial 1) was located along the northeastern perimeter of House 2 (see below)

House 3 overlapped House 2, and may have predated it, given one instance of a House 2 post intersecting a House 3 post (see Figure 5). It was $9.75 \mathrm{~m}$ in diameter, and similar in shape and design to House 2, with the exterior posts approximately $0.6 \mathrm{~m}$ apart. There may have been two entrances to House 3 , one consisting of a $0.9 \mathrm{~m}$ gap in the east wall, and another in the southwestern corner. This possible entrance also had a "very dark, heavy midden" deposit (see Figure 5). House 3 also had a central hearth, $60 \mathrm{~cm}$ in diameter and $30 \mathrm{~cm}$ deep, but no mention was made of a center post under it. A pit feature, $60 \mathrm{~cm}$ in diameter and $30 \mathrm{~cm}$ in depth, was present in the house interior, but its contents are unknown.

Mr. Whiteside recorded no other excavated houses at the Bryan Hardy site, but in one diagram found in his notes, he showed an arc of five post holes $6 \mathrm{~m}$ east of House 1 . Also 


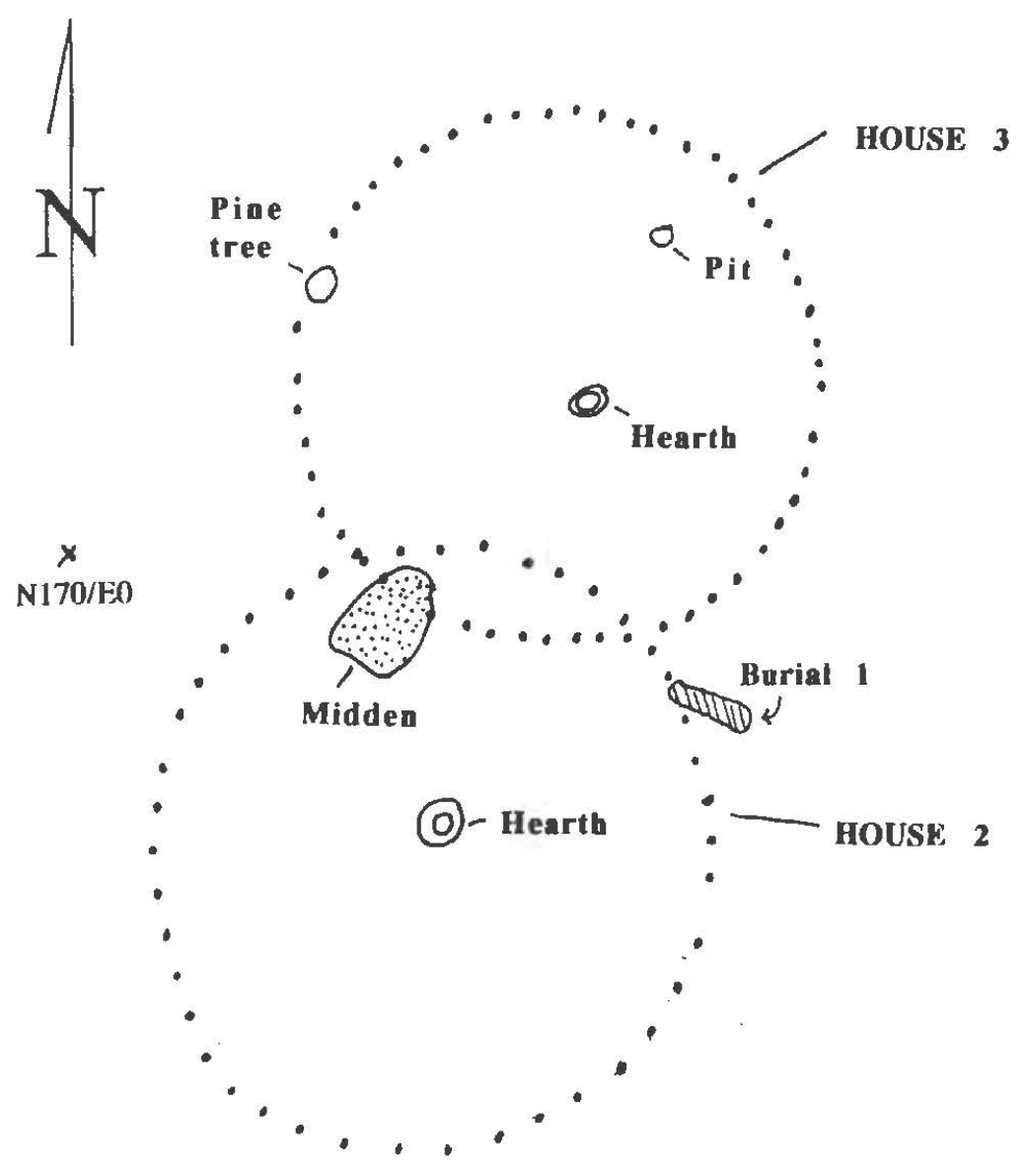

Figure 5. Plan map of Houses 2 and 3.

in his collections was a large piece of charcoal that came from a $30 \times 46 \mathrm{~cm}$ posthole. The charcoal was White Oak, and was probably from a tree that was 100-200 years old (David H. Jurney, 1998 personal communication).

\section{Burials}

Burial 1 was discovered during the excavations of House 2. It was on the northeastern side of the house, and the burial pit extended into the house between two posts. The individual was placed in the burial pit with its head to the southeast, and it was laid in an extended supine position. Three small ceramic vessels were placed along the individual's right side, near the waist. The small size of the offerings, and its placement partially inside the house, suggest that Burial 1 was an infant. Unfortunately, the poorly preserved skeletal materials could provide no further indication of the age or sex of the deceased. The three ceramic vessels placed with Burial 1 included a plain bowl (10.2 $\mathrm{cm}$ in diameter), an effigy bowl ( $7.6 \mathrm{~cm}$ in diameter), and a $7 \mathrm{~cm}$ long dipper or spoon (Figure 6).

Burials 2 and 3 were $5.5 \mathrm{~m}$ southeast of House 1 (see Figure 1), and paralleled each other; they were $1.7 \mathrm{~m}$ apart, and both were oriented southeast to northwest. Burial 2 was placed in a $66 \mathrm{~cm}$ deep pit excavated into the red clay. The pit fill had small charcoal flakes, small bits of animal bone, and pottery sherds. The individual was in an extended supine position, with the head to the southeast, and facing up. The skeletal remains were poorly preserved, as only the back of the skull and teeth remained in the pit. A single offering placed near the 


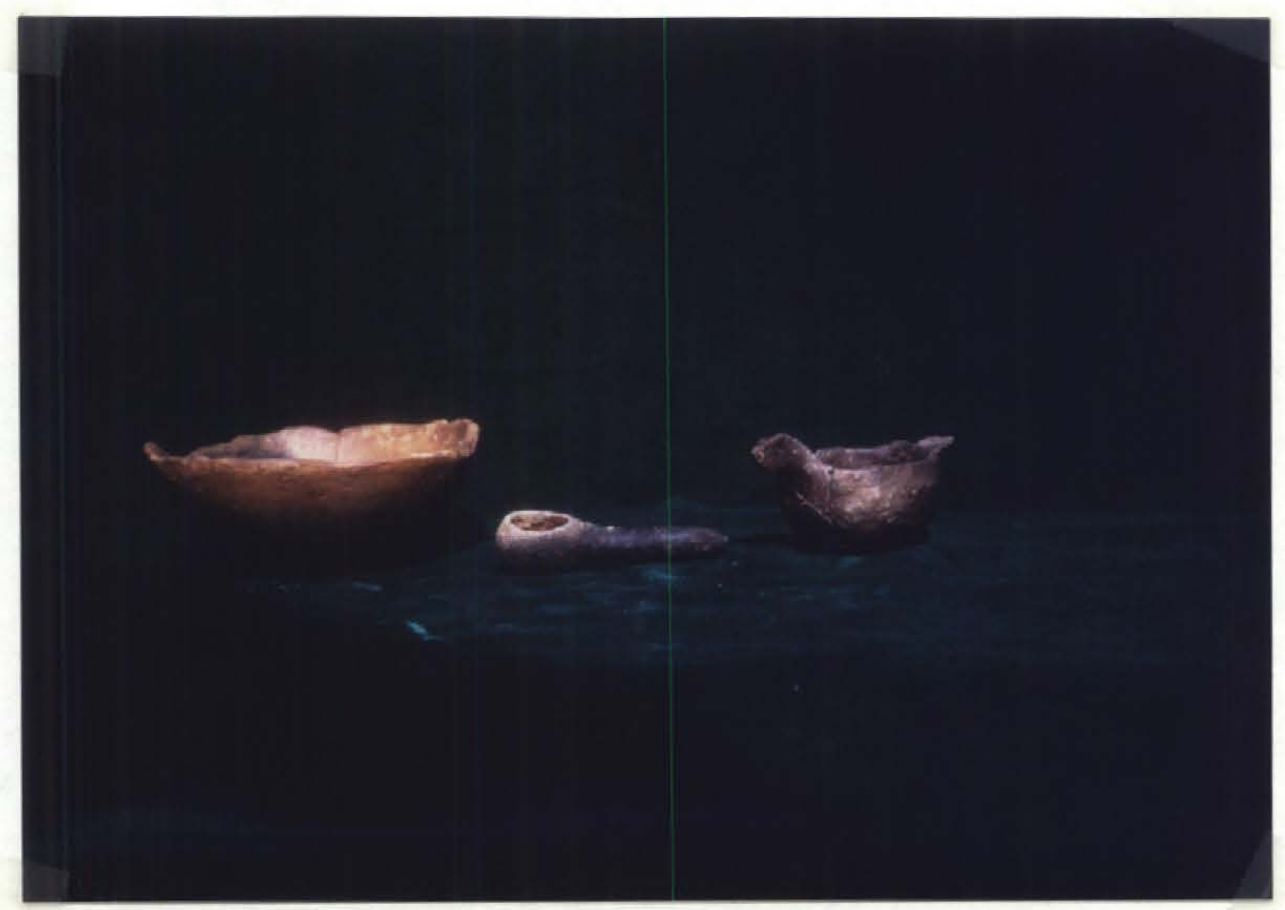

Figure 6. Burial 1 Artifacts.

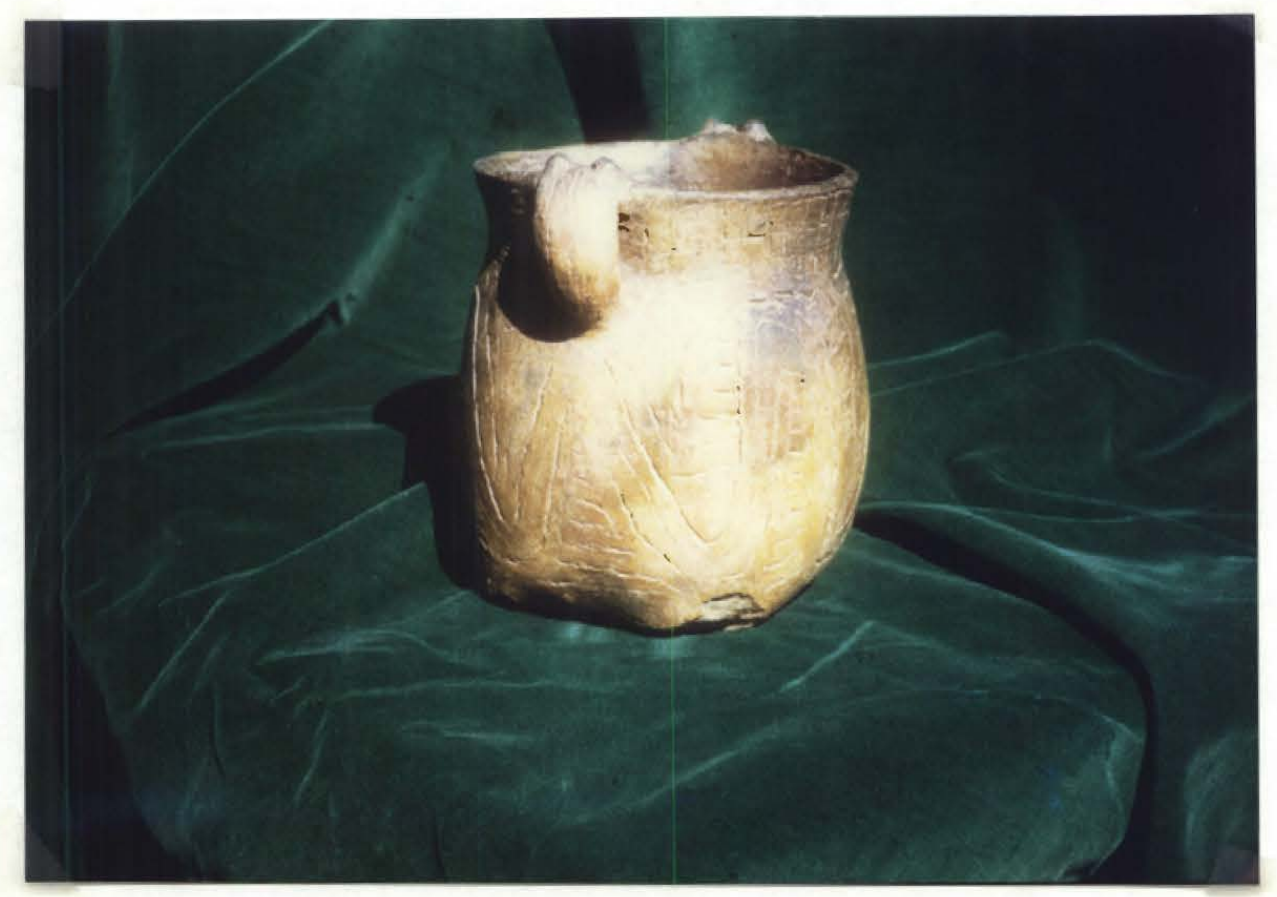

Figure 7. Burial 2 Vessel. 
right shoulder was a $12.7 \mathrm{~cm}$ high vessel with two strap handles and four broken legs (Figure 7).

The vessel has horizontal and vertical incised lines on the rim and body, and Jelks (August 21, 1958 personal communication to Sam Whiteside) stated that it appeared to be a Monkstown Fingernail Impressed vessel, or else a variety of Killough Pinched. This vessel from Bryan Hardy fits the Monkstown Fingernail Impressed description given by Suhm and Jelks (1962) as to form, vessel shape and size, and decoration (particularly the handles [see Suhm and Jelks 1962:Plate 55B, C]), except for the four vessel legs. Equally perplexing was the absence of similar decorated examples in the sherd collection, and most punctated elements were randomly placed on vessel bodies, while those punctated sherds with elements placed in lines were usually made with a tool, not a fingernail. There are examples of Killough Pinched in the decorated sherds, as well as a ring base.

Burial 3 was extended, with the head to the southeast, and the head was turned slightly to the left. No cranial deformation or modeling was noted. Other preserved skeletal remains included portions of the leg and arm bones. The burial pit fill was a mixture of sherds, charcoal flakes, and animal bone, including a deer mandible. The single funerary object was a shallow carinated bowl (12 $\mathrm{cm}$ in diameter) with a unique engraved design placed between two horizontal engraved lines at the top and bottom of the rim (Figure 8). There were four equally spaced rim peaks on the carinated bowl.

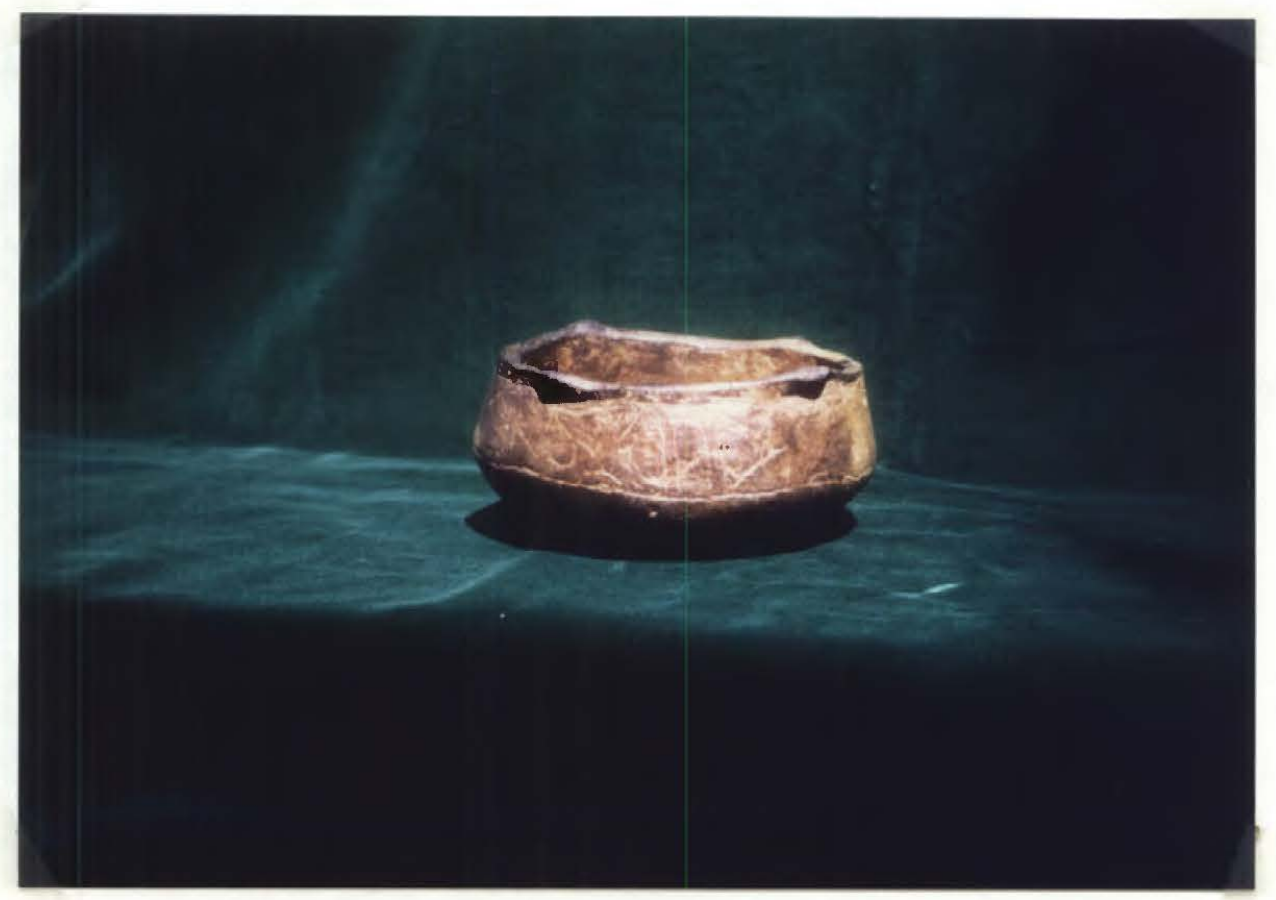

Figure 8. Burial 3 Engraved Vessel. 


\section{ARTIFACTS FROM THE BRYAN HARDY SITE}

A total of 1732 artifacts were recovered at the Bryan Hardy site, including whole vessels, during the 1958 archeological investigations by Sam Whiteside. This includes 1682 plain and decorated ceramic sherds, 5 ceramic vessels, 11 pieces of daub/fired clay, and 39 lithic artifacts (Table 1).

Table 1. Inventory of Artifacts from the Bryan Hardy Site (41SM55)

Ceramics

5 whole vessels

847 plain body sherds

636 decorated body sherds

13 pinched-punctated

29 punctated-incised

9 interior decorated

172 punctated

113 brushed-punctated

1 appliqued

6 red slipped

149 brushed

103 incised

2 brushed-incised

35 engraved

4 brushed-punctated-incised

37 plain rim sherds

94 decorated rim sherds

13 engraved

1 brushed-punctated-incised

2 pinched-punctated

11 punctated-incised

11 punctated

5 brushed-incised

1 brushed-punctated

1 scalloped

49 incised

1 base ring sherd

65 plain base sherds

2 perfordted base sherds

11 daub/fired clay

Lithics

35 lithic debris

4 chipped stone tools 


\section{VESSEL CERAMICS}

"The ceramics from this site [Bryan Hardy] resemble Alto Focus in paste, rim form, and in some of the decorative techniques. Fulton traits are also present, however, including brushing and engraving technique. It is especially striking to see many body sherds with characteristically Fulton Aspect brushed background and characteristically Alto Focus punctating" (August 21, 1958 letter from Edward B. Jelks to Sam Whiteside).

During the excavations at Bryan Hardy, Sam Whiteside recovered and catalogued 1682 ceramic sherds from vessels, as well as the five vessels discussed above. Table 2 provides information on the surface treatment of the sherds from the site.

\section{Table 2. Ceramic Surface Treatment}

\begin{tabular}{|c|c|c|}
\hline Decorated Body Sherds $(n=636)$ & $\mathrm{N}$ & Percent \\
\hline Punctated & 172 & 27.0 \\
\hline Brushed & 149 & 23.4 \\
\hline Brushed-Punctated & 113 & 17.8 \\
\hline Incised & 103 & 16.2 \\
\hline Engraved & 35 & 5.5 \\
\hline Punctated-Incised & 29 & 4.6 \\
\hline Pinched-Punctated & 13 & 2.0 \\
\hline Interior Decorated & 9 & 1.4 \\
\hline Red Slipped & 6 & 0.9 \\
\hline Brushed-Punctated-Incised & 4 & 0.6 \\
\hline Brushed-Incised & 2 & 0.3 \\
\hline Appliqued & 1 & 0.2 \\
\hline Decorated Rim Sherds $(n=94)$ & $\mathrm{N}$ & Percent \\
\hline Incised & 49 & 52.1 \\
\hline Engraved & 13 & 13.8 \\
\hline Punctated & 11 & 11.7 \\
\hline Punctated-Incised & 11 & 11.7 \\
\hline Brushed-Incised & 5 & 5.3 \\
\hline Pinched-Punctated & 2 & 2.1 \\
\hline Brushed-Punctated-Incised & 1 & 1.1 \\
\hline Brushed-Punctated & 1 & 1.1 \\
\hline Scalloped & 1 & 1.1 \\
\hline Plain and Decorated Rim Sherds $(n=131)$ & $\mathrm{N}$ & Percent \\
\hline Incised & 49 & 37.4 \\
\hline Plain & 37 & 28.2 \\
\hline Engraved & 13 & 9.9 \\
\hline Punctated & 11 & 8.4 \\
\hline Punctated-Incised & 11 & 8.4 \\
\hline Brushed-Incised & 5 & 3.8 \\
\hline Pinched-Punctated & 2 & 1.5 \\
\hline Brushed-Punctated-Incised & 1 & 0.8 \\
\hline Brushed-Punctated & 1 & 0.8 \\
\hline Scalloped & 1 & 0.8 \\
\hline
\end{tabular}


Table 2. Ceramic Surface Treatment, cont.

\begin{tabular}{cll}
\hline Total Sherds $(\mathrm{n}=1682)$ & $\mathrm{N}$ & Percent \\
Plain Body & 847 & \\
DecoratedBody & 636 & 50.4 \\
Plain Rim & 37 & 37.8 \\
Decorated Rim & 94 & 2.2 \\
Plain Base & 65 & 5.6 \\
Base Ring & 1 & 3.9 \\
Perforated Base & 2 & 0.06 \\
\end{tabular}

Sherd temper was predominantly grog and bone, with only a minor number of sherds with additional sand-grit inclusions beyond the typical amount already present in the clays used to manufacture the vessels. In the fine wares (i.e., the engraved sherds), the tempering materials were more finely ground and sieved, but still consisted of a grog-bone mixture in the clay paste.

A total of 65 base sherds are present in the ceramic assemblage (see Table 2). They are flat, thicker than the body walls--up to $20 \mathrm{~mm}$ in thickness--and they were generally well-fired. The bases appear to have been made separately, then coils were added to make the vessel walls; many sherds have breaks where the first coil attaches to the base. Another base sherd is a base ring to a Killough Pinched vessel.

The decorated sherds were divided between body and rim (see Table 2) because of the common practice of prehistoric Caddo potters to have one dominant design element--in this case punctating ( 27 percent)--on the body of the vessel, and another separate element (incising, at 52 percent) on the rim.

\section{Decorated Body Sherds}

Fifty-two percent of the body sherds have some form of punctated design, either by itself or in combination with another design elements (Figures 9-11). Alone, punctated sherds occur on 27 percent of the body sherds. Among these, 60 percent have random tool punctations, 37 percent have random fingernail punctations, and two sherds (both from bottles) have punctated designs in horizontal rows.

Forty-two percent of the decorated body sherds have brushed designs (see Table 2), and slightly more than 55 percent of these simply have brushed marks; the other brushing occurs in combination with punctations, or incised lines, or punctations and incised lines (Figures 12 and 13). All but four of the brushed sherds have random brush marks; the others have parallel brushed lines. The brushed sherds are from thick utilitarian vessels with smoothed interiors.

The brushed-punctated sherds have brushed backgrounds along with random fingernail punctations $(n=68)$ or large tool punctations $(n=41)$; two sherds have rows of punctations. These sherds are also from large utility wares, and are primarily light tan to brown in color.

Incised body sherds are common, representing 16 percent of the decorated body sherds (see Table 2). Another 5.5 percent had combinations of punctated, brushed, or brushedpunctated elements along with the incised design elements (Figure 14). Of the incised body 


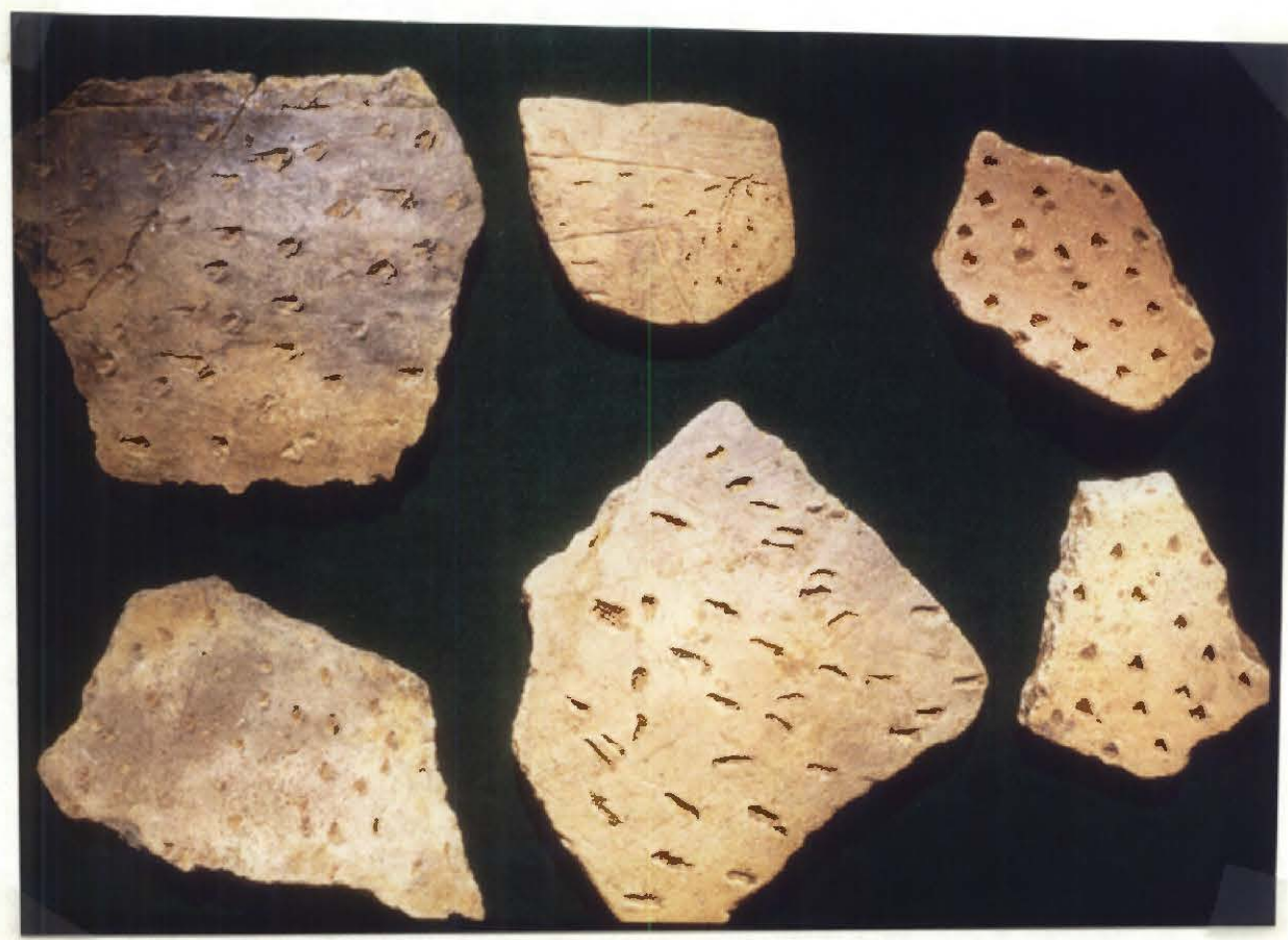

Figure 9. Punctated and Punctated-Incised Body Sherds.

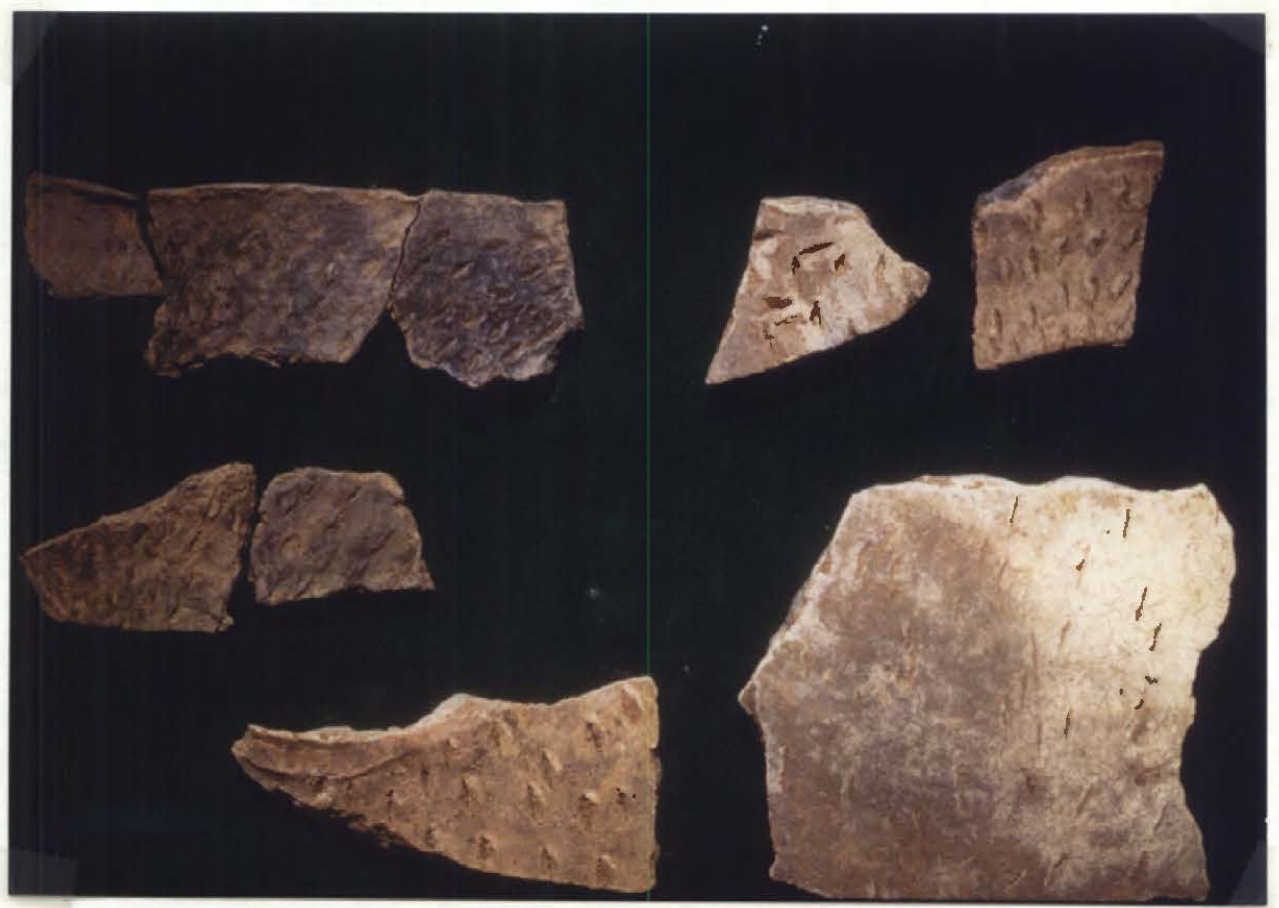

Figure 10. Punctated Body and Rim Sherds. 


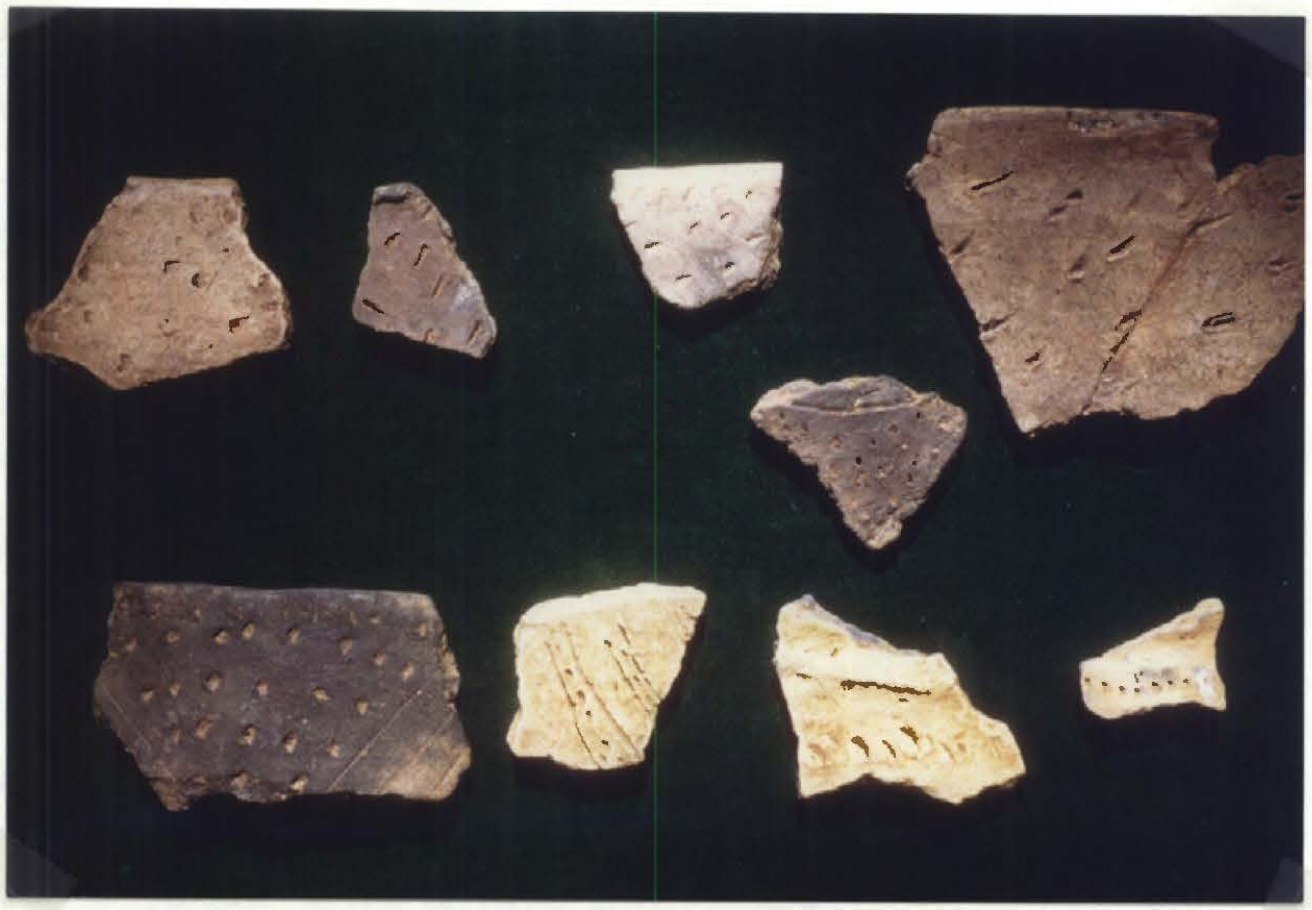

Figure 11. Punctated and Punctated-Incised Body and Rim Sherds.

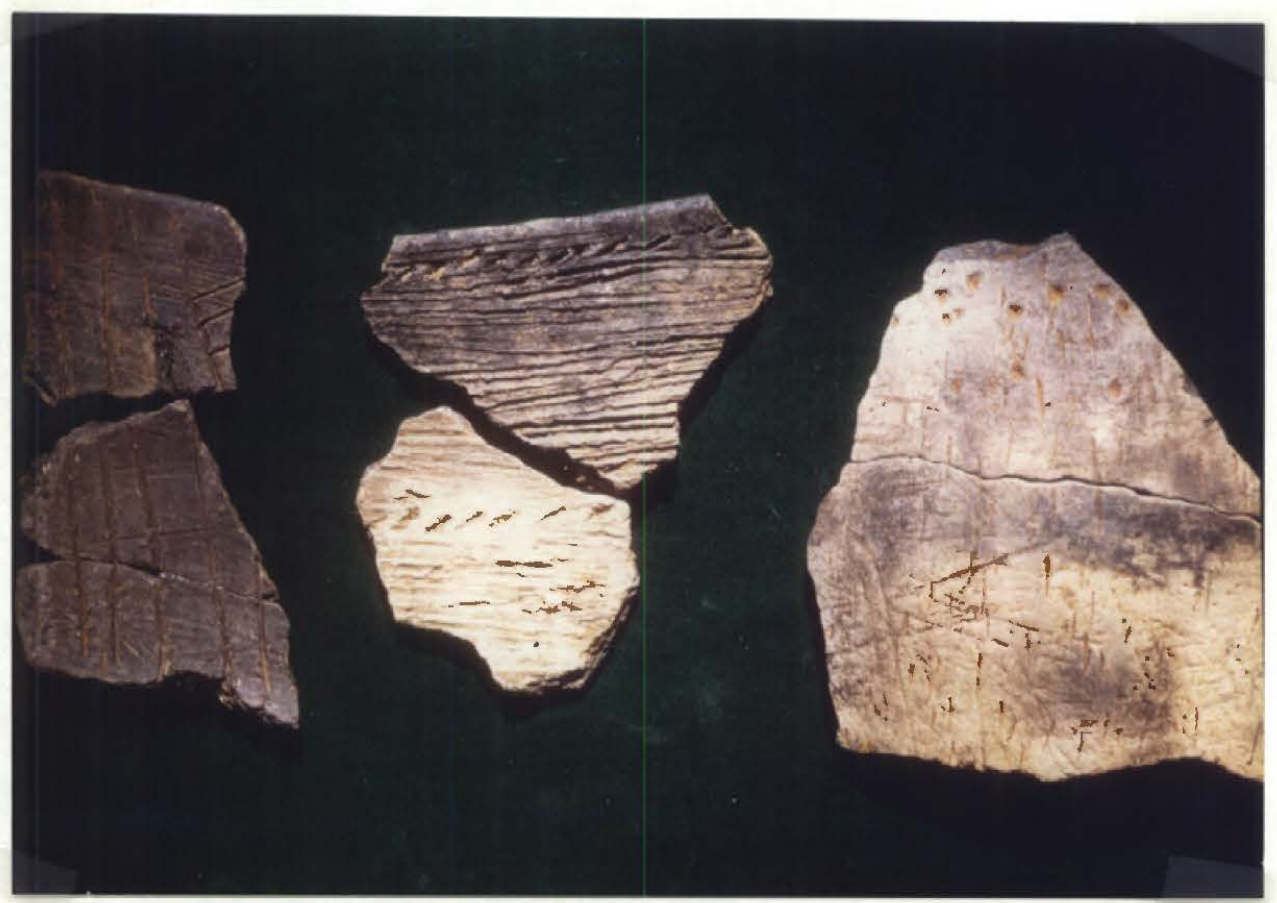

Figure 12. Brushed-Incised and Brushed-Punctated Body and Rim Sherds. 


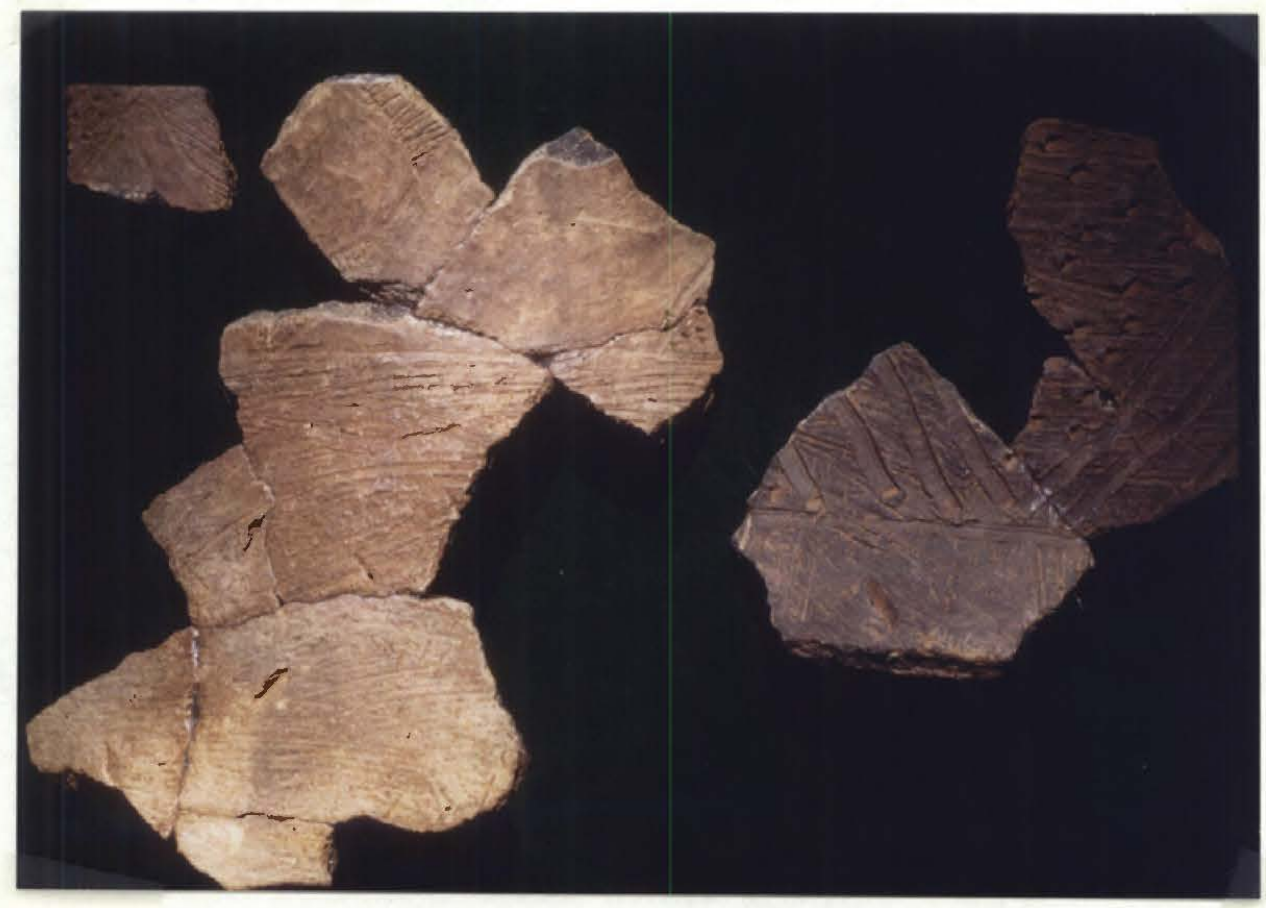

Figure 13. Brushed-Punctated Body and Rim Sherds.

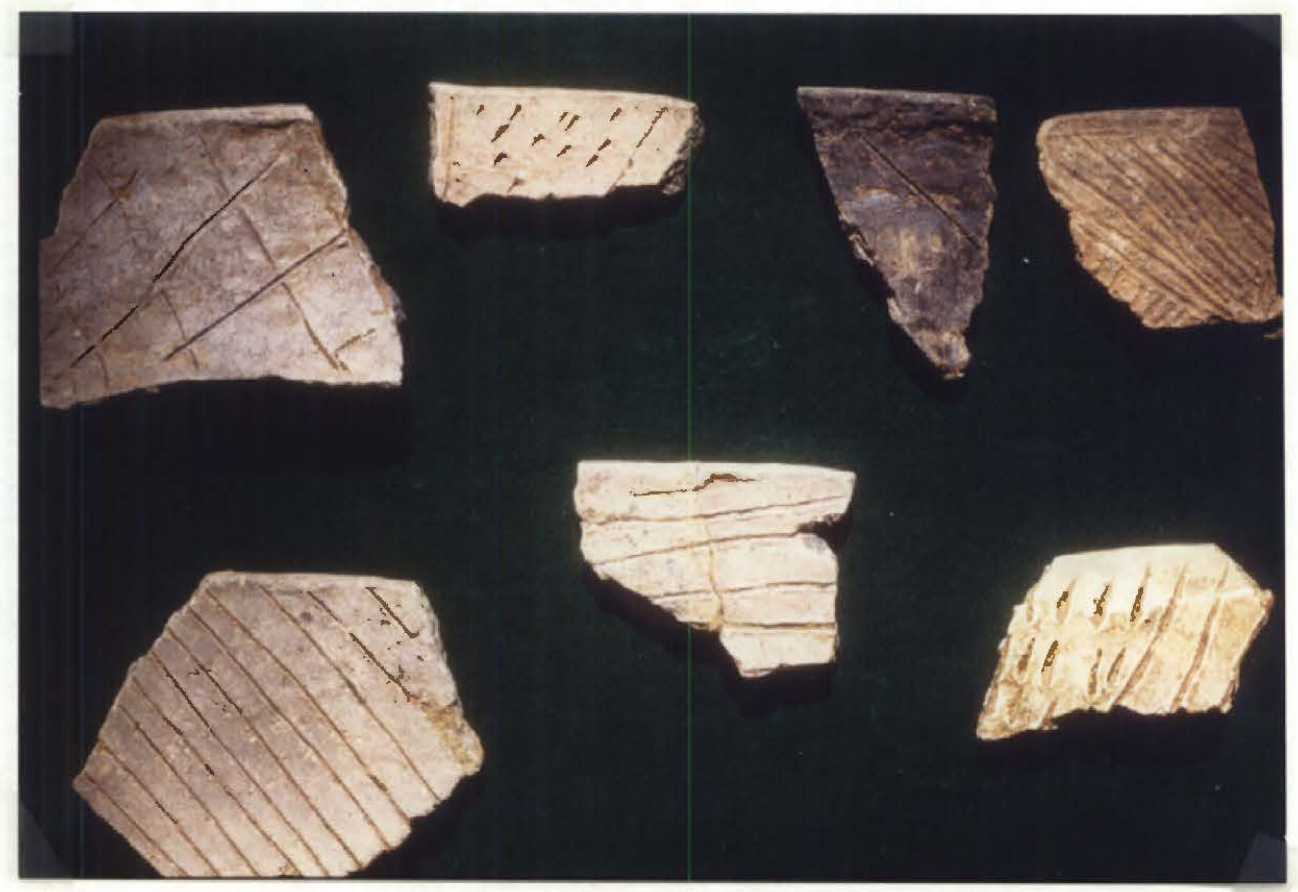

Figure 14. Incised and Incised-Punctated Rim Sherds. 
sherds, 53 percent have parallel incised lines, 32 percent have cross-hatched designs, and 14 percent have opposed incised lines.

Engraved designs occur on bottles and carinated bowls (Figures 15-17). The design clements on bowls are defined by horizontal lines at the lip and the point of carination. Twenty-three percent of the engraved body sherds have straight lines that are perpendicular to each other. Other design elements include concentric circles; horizontal lines with attached concentric circles; rectangular blocks or zones filled with cross-hatching; filled pendant triangles; single straight lines; "brick wall" designs; and negative circles outlines with cross-hatching. The engraved sherds are thinner than the utility wares, and range from light tan to brown, red, and black in color.

Most of the punctated-incised body sherds ( 76 percent) have zones of punctations separated by straight incised lines or incised lines that form triangles. Three sherds have parallel incised lines filled with small punctations. There are 23 punctated-incised sherds with tool punctations; six have fingernail punctations.

The pinched-punctated design element appears to have been formed by pressing the two thumbs together in moist clay, raising an area in the middle, and leaving fingernail impressions on either side (Figure 18). Two of these sherds have shaped rows of ridges, while the remainder have pinched-punctated designs that covered the entire surface. After the ridges were formed, they were smoothed to leave a flat exterior vessel surface.

Nine sherds from House 1 have heavily brushed-incised interior surfaces. Six of them were plain on the exterior surface, while three others have punctated designs. This group of sherds are thick compared to the other utility wares.

The red slipped sherds have a very dark red hematite-rich clay slip; they are otherwise plain. One thicker body sherd has an eroding red slip.

Two sherds from the same vessel have heavily brushed bodies with large tool punctations (see Figure 13). The rim element is separated from the body by a horizontal line with opposing lines that form a punctated-filled triangle. A third sherd has parallel incised lines placed over a brushed background that has randomly placed gouged punctations. The last of the brushed-punctated-incised sherds has horizontal brushing on the rim with small clusters of punctations. The body has circular lines with cross-hatching filling the connecting lines (Figure 19). This vessel was dubbed "Hardy Incised" by Mr. Whiteside (see Whiteside 1959). The vessel section appears to be $23 \mathrm{~cm}$ in maximum diameter and has $6 \mathrm{~mm}$ thick vessel walls.

There are two brushed-incised body sherds in the Bryan Hardy site collections. These have brushed backgrounds with overlying parallel incised lines.

The one body sherd with an appliqued design has a horizontal appliqued fillet on a plain vessel surface. 


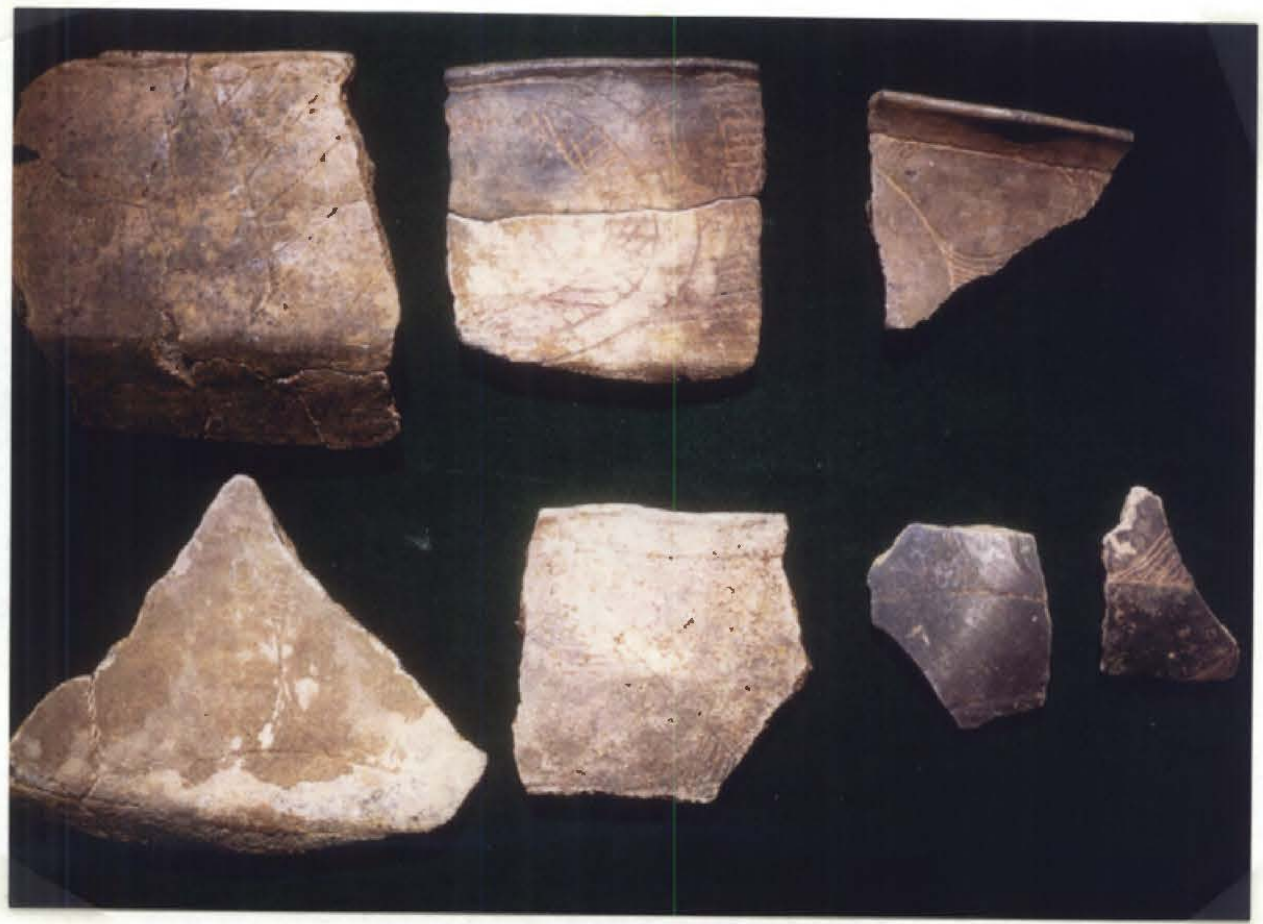

Figure 15. Engraved Body and Rim Sherds. Sherds at top and lower left have inverted rims.

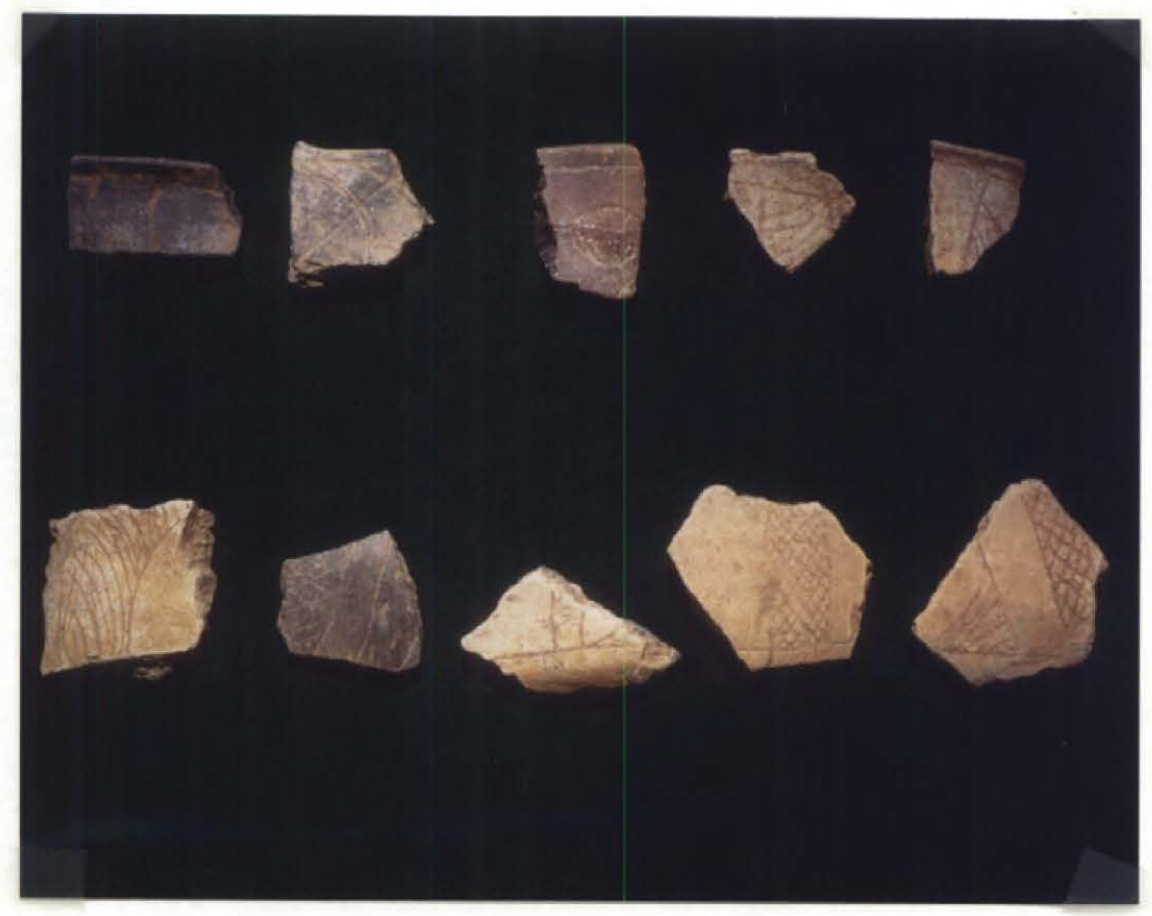

Figure 16. Engraved Rim and Body Sherds. 

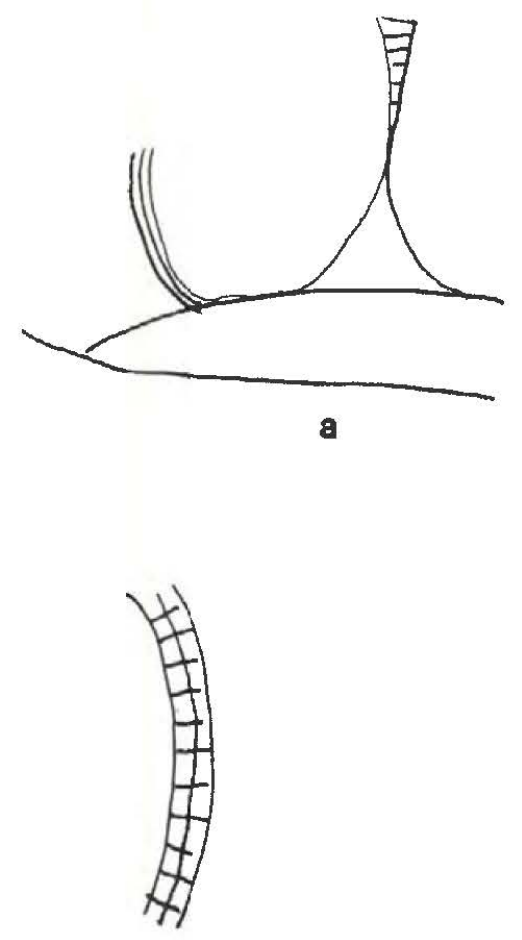

c
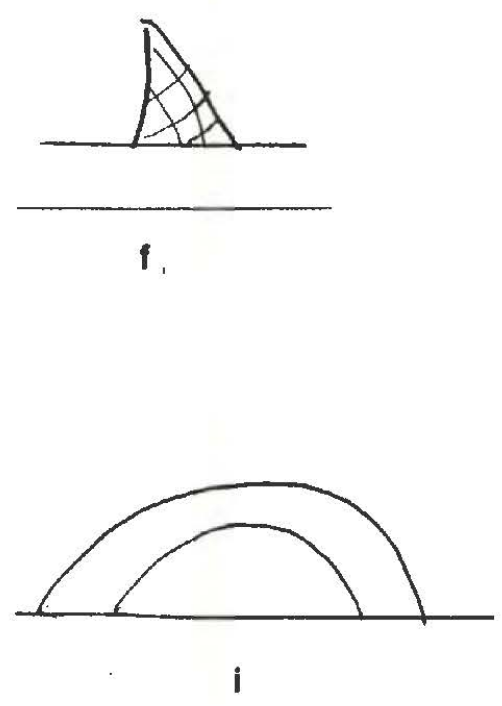

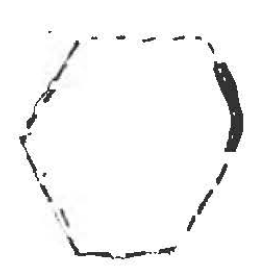

a1 sherd profile
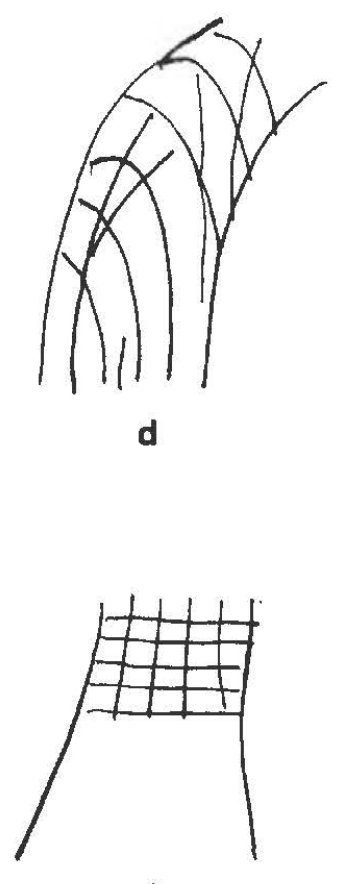

g
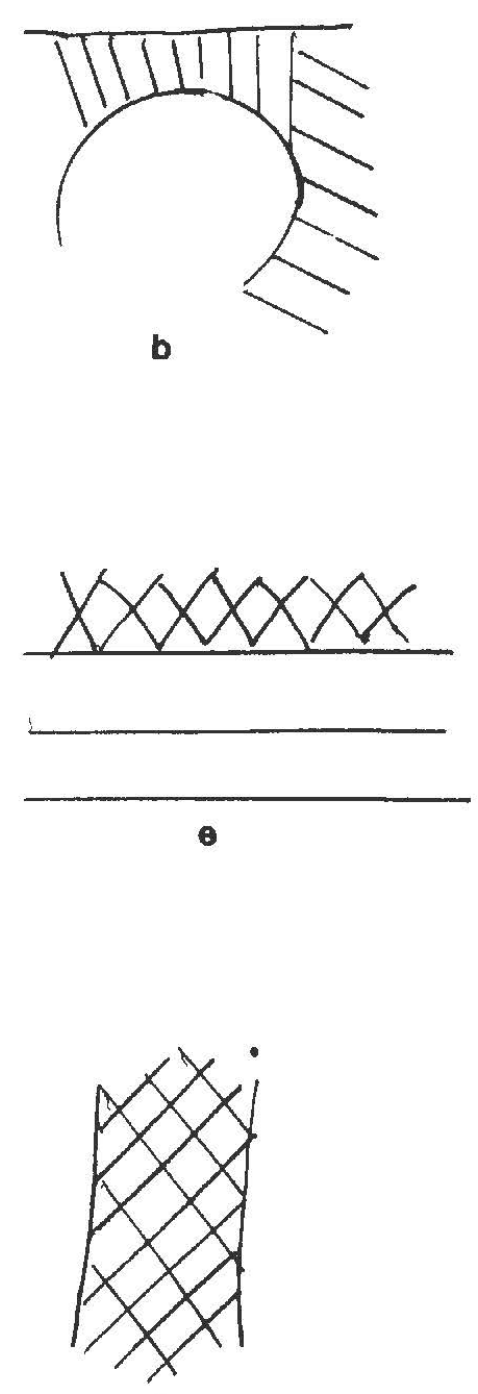

h

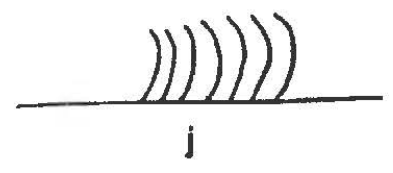

Figure 17. Engraved Body Sherd Design Elements. 


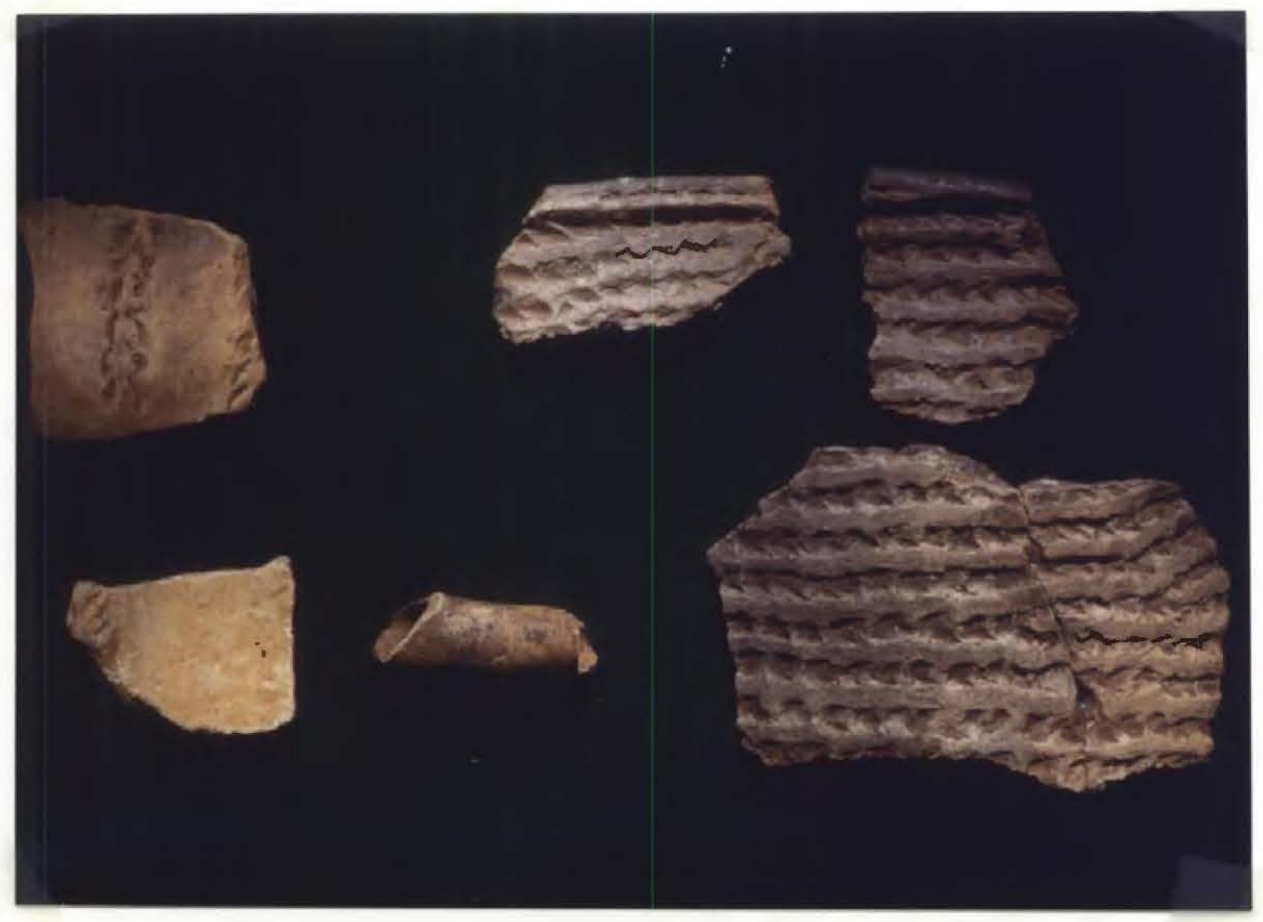

Figure 18. Pinched-Punctated Rim and Body Sherds. Note pipe sherd in center, lower row.

\section{Plain and Decorated Rim Sherds}

Of the 131 rim sherds (see Table 2), 28 percent are from plain vessels (Figure 20). Almost 60 percent of the plain rims have a straight or vertical rim profile with flat lips. Another 10 are straight with rounded lips, and five have an exterior folded or rolled out lip, and resemble a pie crust (Figure 21). One plain rim from a carinated bowl has a scalloped lip; a $5 \mathrm{~mm}$ wide drilled suspension hole is $4 \mathrm{~cm}$ below the lip.

Rim sherds with incised design elements comprise more than 70 percent of the decorated rims from Bryan Hardy (see Table 2), and 73 percent have only incised designs. Twentyone incised rims have parallel diagonal lines, and they are mainly straight $(n=16)$; the other five rims are everted. Lips are flat $(n=13)$ and rounded $(n=8)$. Cross-hatched incised rims total 15,11 with straight rims and four with everted rims. Lips are flat $(n=11)$ or rounded $(n=4)$. There are eight incised rims with either intersecting or diagonal incised lines that have attached perpendicular lines. These have straight rims, five with flat lips and three that are rounded. Four other incised rims have a single horizontal line below the lip; three have straight rims and the other is inverted; lips are flat $(n=3)$ and rounded $(n=1)$. One incised rim has multiple incised lines beginning below the lip. It has a flat lip and an inverted rim.

There are a variety of design elements in the engraved rims, and most of them are within horizontal panels. The most common elements are circular lines that form borders of negative ovals or opposing straight lines, circles filled with straight lines, triangles or right angles with filled corners, and parallel straight lines (Figure 22; see also Figures 15 and 


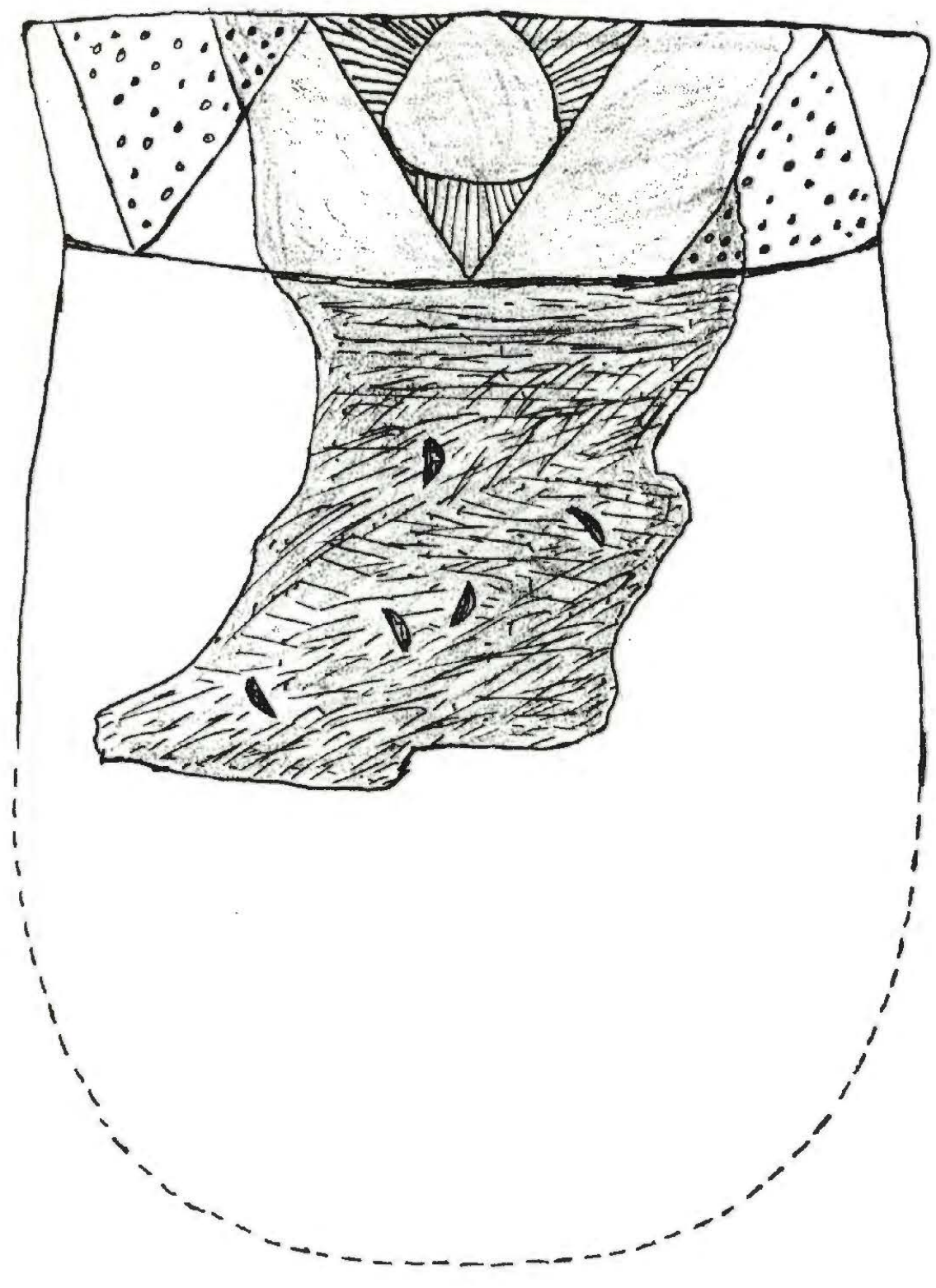

Figure 19. "Hardy Incised" Vessel Drawing. 


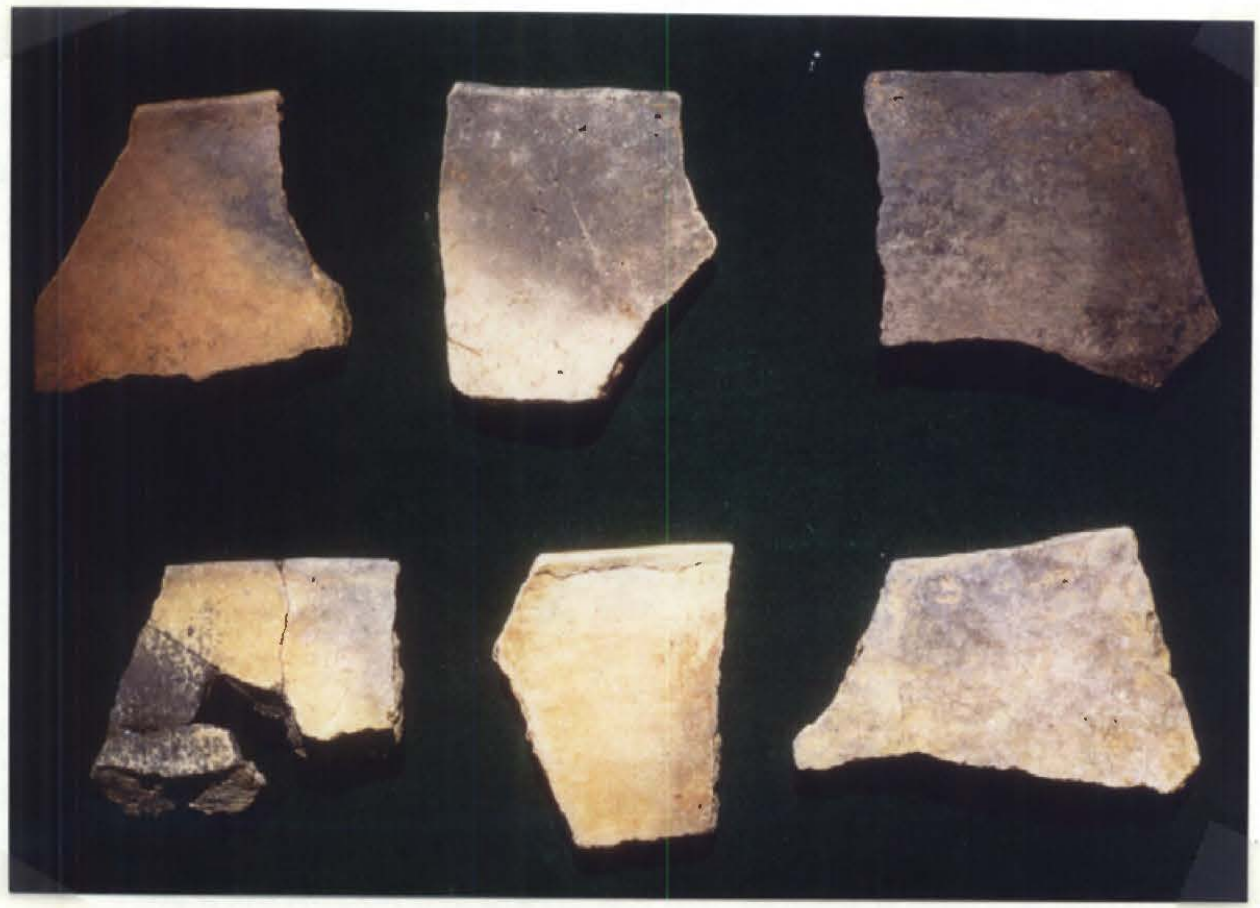

Figure 20. Plain Rim Sherds.

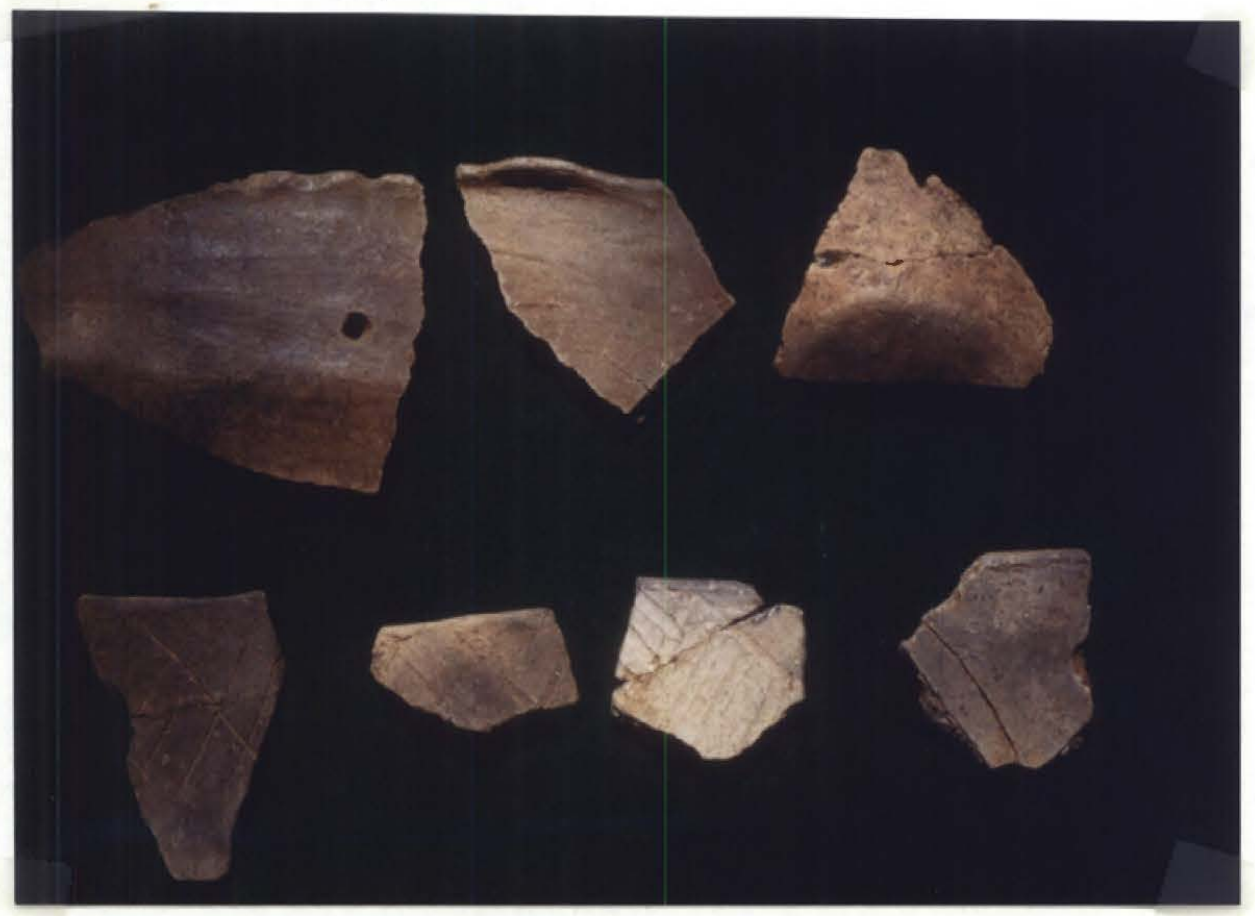

Figure 21. Rim Sherds: top row, plain; bottom row, incised. 


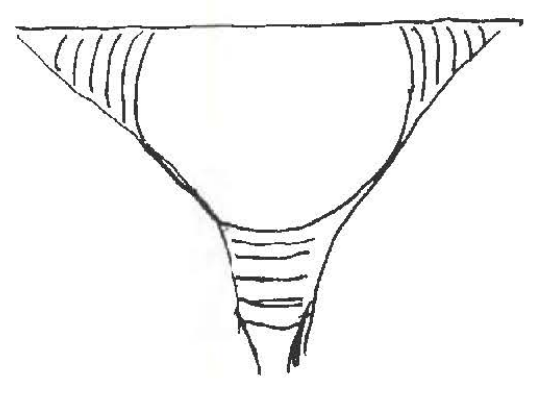

a

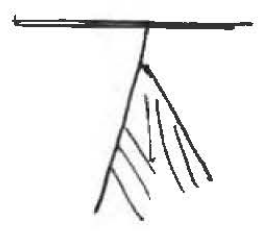

c

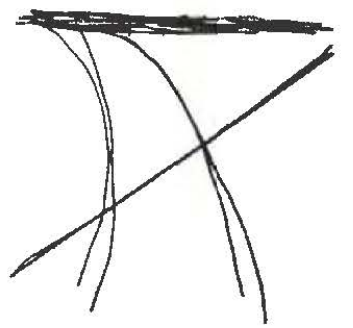

$f$

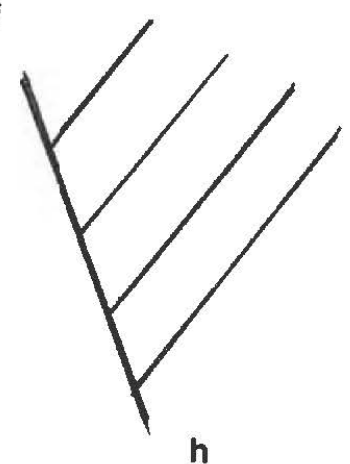

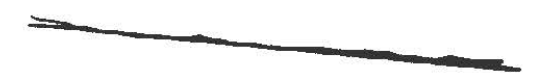

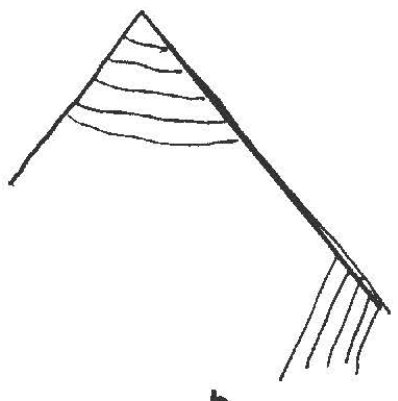

b
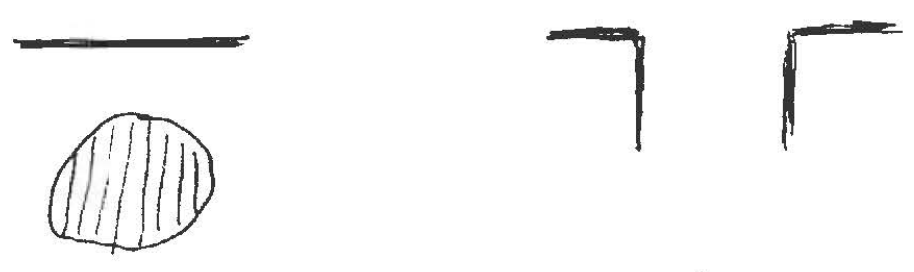

d

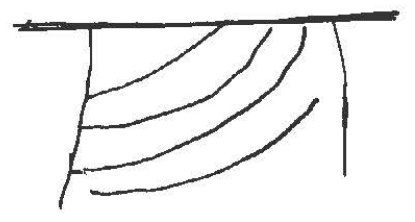

g

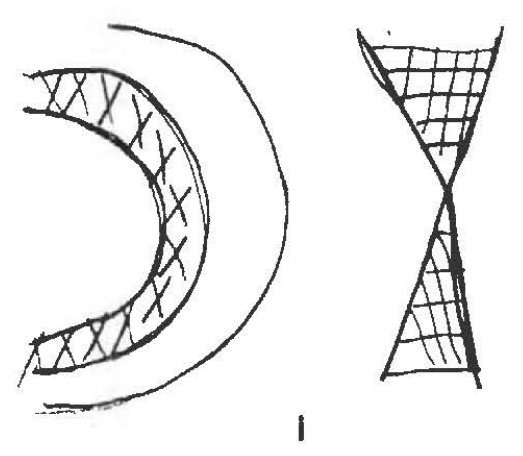

Figure 22. Engraved Rim Sherd Design Elements. 
16). The engraved rims have flat $(n=10)$, rolled out $(n=2)$, and round and peaked $(n=1)$ lips; one of the flat lips also has a "piecrust" profile.

Punctated decorations occur in some combination on 27 percent of the decorated rims; 11 percent have punctations alone. All of the latter rims have randomly placed tool punctations (see Figures 10 and 11), except for one that has a horizontal row of cane punctations below the lip. Seven of the punctated rims have flat lips, and four are rounded. Five of the rims are everted, with the remainder either straight or undetermined. The punctated rims are from vessels with smoothed interiors, and they have light tan to black colors.

Seventy-three percent of the punctated-incised rims have diagonal incised lines that separate zones of punctates (one fingernail punctated and seven with a tear-shaped tool). Three sherds have zones of round punctates separated by either empty triangles or punctated-filled triangles. The rims are straight, but seven have round lips and four are flat.

Of the five brushed-incised rims, three have vertical brushing and two have horizontal brushing. The incised lines form cross-hatched, diagonal, and opposed design elements. Four of the five rims have everted profiles, and the other is straight; three have flat lips and two are rounded. None of the rims have brushing as the sole design element, and only seven percent of the 94 decorated rims have a design that combines brushing with other elements; brushing was predominantly a body treatment.

There are two pinched-punctated rims, both everted, with round and rolled out lips. The design consists of solid horizontal rows of pinching-punetations. The ridges formed by the pinching have been smoothed. The pinched rim sherds are black in color, indicating they are from vessels that have been reduced during firing.

The one brushed-punctated-incised rim has horizontal brushing with random tool punctations separated from the brushing by a diagonal incised line. The rim has a flat lip. There is also a brushed-punctated rim with an everted profile and a rounded lip. The design element consists of heavy horizontal brushing with a horizontal row of tool punctations below the lip.

\section{FIRED CLAY/DAUB}

There are 11 pieces of fired clay/daub, the largest $4 \times 2.5 \mathrm{~cm}$ in length and width. Two had impressions of grass or small reeds. They were light gray to dark brown in color, and none of the pieces had any tempering materials.

\section{DRILLED CERAMIC BASES}

Two base sherds had 1.25-1.5 $\mathrm{cm}$ holes drilled in their centers. One drilled ceramic base also appeared to have had its edges ground for some unknown use.

\section{CERAMIC PIPES}

No ccramic pipes were in the collection, but a photograph of artifacts from Bryan Hardy includes a portion of a long-stemmed Red River type pipe (see Figure 18). 


\section{LITHIC ARTIFACTS}

There were 39 lithic artifacts from Bryan Hardy, including 35 pieces of lithic debris (4 primary flakes, 15 secondary flakes, 8 thinning flakes, and 8 debitage). The chipped stone tools include the tip of a large biface, a $6 \mathrm{~cm}$ long and roughly flaked quartzite biface, a 2.7 $\mathrm{cm}$ long Gary dart point of a heat-treated quartzite (it had cortex on the stem), and a serrated Perdiz arrowpoint (Figure 23).

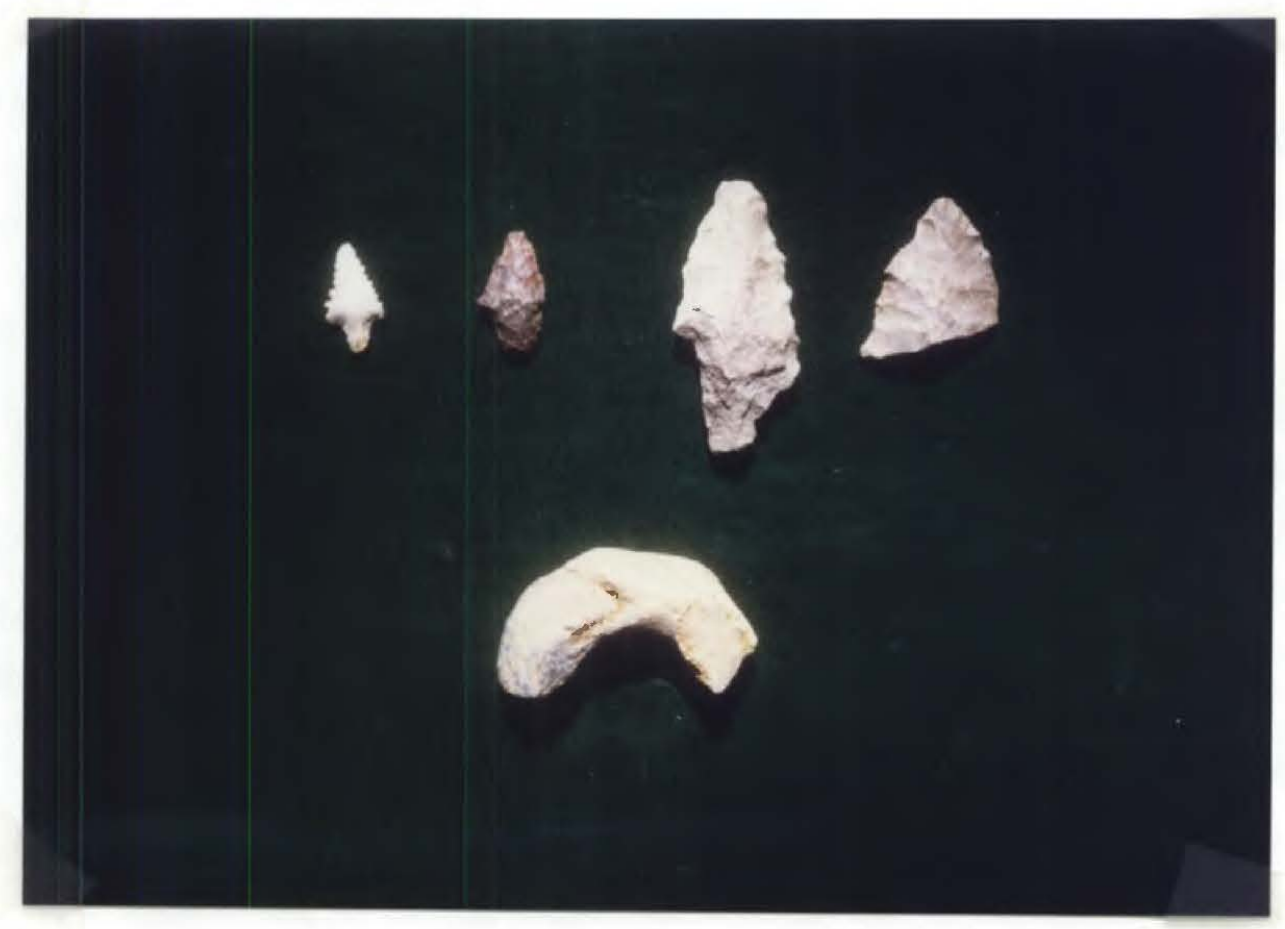

Figure 23. Lithic Tools and Ceramic Ring Base.

The Perdiz arrowpoint was found in a House 3 posthole. The point was concave on one side, with cortex on the stem, and it measured $24 \times 13 \times 4 \mathrm{~mm}$ in length, width, and thickness. It was made from a grayish-white chert with small white inclusions.

\section{SUMMARY}

The Bryan Hardy site is quite similar to several other Middle Caddoan sites in the general area in that they are located on landforms that had no history of previous occupations, they are considerable distances from available water, apparently are occupied year-round for short periods of time (20+ years), and have a single earthen mound covering a burned house. Whether this was the typical settlement pattern in the Middle Caddoan period is unknown, as is their association with other homesteads or larger centers.

The Bryan Hardy mound, and the mounds at related Middle Caddoan sites, appear to have been constructed in a single episode, perhaps as a terminal event. Possible triggering actions could have included disease, death and the resultant need for purification, or site abandonment or termination. It is interesting that a carinated bowl from the Redwine site 
(41SM193), one of the related Middle Caddoan mound sites, depicts what appears to be a sequence of house forms from small to large in size, with one showing smoke rising from it; the next sequence in the engraved design has a house with a semi-circle outlining it, which may represent a covering or mound, with what may be interpreted as flames emitting from it (Walters et al. 1998:Figure 12a).

Within the same drainage (Harris Creek) as the Bryan Hardy site is another mound site, the Redwine site. Investigations by Sam Whiteside (see Walters et al. 1998:22-25) disclosed a circular house with an extended entrance that appears to have been burned and subsequently covered with approximately $1 \mathrm{~m}$ of undifferentiated soil. There also was an intentional mounding or berming of soil or clay around part of the structure. There are two radiocarbon dates from this site. The calibrated age range at 1 sigma of charred nutshells from Feature 3 is AD 1312-1423. Charcoal from Burial 3 yielded a conventional age of 440 \pm 70 B.P. (Beta-133695) and a calibrated age range of $\mathrm{AD} 1398-1636$ at 2 sigma (0.98 relative area under the probability distribution).

In Panola County, Texas, on Iron's Bayou in the Sabine River drainage, an unexcavated circular mound is reported at $41 \mathrm{PN} 149$, adjacent to a midden area from which maize yielded a corrected radiocarbon age range of A.D. 1475-1527 (Beta-124359). This mound is approximately $8 \mathrm{~m}$ in diameter and $1 \mathrm{~m}$ in height. This site, like Bryan Hardy and Redwine, is located a long distance from water, on a landform well above the floodplain, and occupied for a short period of time. Although there are temporal and spatial differences between these sites, they share common ceramic assemblages: bone-tempered and bonegrog-tempered wares; similar vessel shapes; and similar decorative elements, particularly in the brushed and engraved wares. The pottery at each of the sites is consistent with Middle Caddoan period wares documented elsewhere in the middle reaches of the Sabine River basin at that time.

No faunal remains or charred plant remains have been recovered at the Bryan Hardy site, although its location and associated soils point towards the possibility that limited agricultural activities took place during the site occupation. The number and size of the ceramic vessels found here suggests that the storage of some unknown products, perhaps foodstuffs, was an important characteristic of the Middle Caddoan occupation.

Our study of the Bryan Hardy ceramics has noted the following: (a) temper is predominantly bone and bone-grog; this temper is absent or rare in later Caddoan sites in the general area; (b) the lip form is primarily flat or round; and (c) vessel forms--with the exception of Poyner Engraved style carinated bowls with inverted rims--were mainly large wide-mouthed containers; engraved bottles with straight necks are present, as are effigy bowls. Design elements include a wide range of stylistic motifs, and punctation is the most common design element, occurring on 52 percent of the decorated sherds; random tool punctates are more common than fingernail punetations. Notable are several sherds that have a brushed background with incised elements and random punctations, such as the "Hardy Incised" vessel. Included in the brushed wares are examples that are similar to Pease Brushed-Incised. There are also several red slipped sherds, but overall, slipping is a minor ceramic style.

The vessel from Burial 2-except for the evidence of four legs--fits descriptions of similar vessels found at the Sanders site on the Red River (Krieger 1946). They occur rarely on the Red River, never south of the Sabine River, and this vessel is probably a trade good. 


\section{ACKNOWLEDGMENTS}

We would like to thank members of Sam Whiteside's family for preserving his notes and artifacts, and for making them available for us to study. The senior author would also like to posthumously thank Uncle Sam for his devotion and careful work that allowed this link to our prehistory to be made public, and for inspiring and helping him as a teenager in a study that now upon retirement has become more than a hobby.

\section{REFERENCES CITED}

Hatherly, D. T.

1993 Soil Survey of Smith County, Texas. United States Department of Agriculture, Soil Conservation Service, in cooperation with the Texas Agricultural Experiment Station and the Texas State Soil and Water Conservation Board.

Krieger, A. D.

1946 Culture Complexes and Chronology in Northern Texas, with Extensions of Puebloan Datings to the Mississippi Valley. Publication No. 4640. The University of Texas, Austin.

Perttula, T. K.

1998 Radiocarbon and Oxidizable Carbon Ratio Dates from Archaeological Sites in East Texas, Part II. Journal of Northeast Texas Archaeology 11:66-90.

Stuiver, M. and P. J. Reimer

1993a Extended ${ }^{\mathrm{i}} \mathrm{C}$ Data Base and Revised CALIB $3.0{ }^{14} \mathrm{C}$ Age Calibration Program. Radiocarbon 35(1):215-230.

1993b CALIB User's Guide Rev 3.0.3A for Macintosh Computers. Quaternary Research Center, University of Washington, Seattle.

Suhm, D. A. and E. B. Jelks (editors)

1962 Handbook of Texas Archeology: Type Descriptions. Texas Archeological Society, Special Publication No. 1, and Texas Mernorial Museum, Bulletin No. 4, Austin.

Walters, M. and P. Haskins, with contributions by D. H. Jurney, S. E. Goldborer, and T. K. Perttula

1998 Archaeological Investigations at the Redwine Site (41SM193), Smith County, Texas. Journal of Northeast Texas Archaeology 11:1-38.

Whiteside, $\mathrm{S}$.

1959 Vessel from the Bryan Hardy Site. Ancient News 1, No. 1. News Letter of the East Texas Archeological Society. 